OPEN ACCESS

Edited by:

Ioan Cristian loja,

University of Bucharest, Romania

Reviewed by:

Simona R. Gradinaru,

University of Bucharest, Romania Alexandru-lonut Petrisor,

Ion Mincu University of Architecture and Urbanism, Romania

*Correspondence: Kristine Valujeva kristine.valujeva@wur.n

Specialty section: This article was submitted to

Land Use Dynamics,

a section of the journal

Frontiers in Environmental Science

Received: 05 August 2020 Accepted: 13 November 2020 Published: 09 December 2020

Citation:

Valujeva K, Nipers A, Lupikis A and Schulte RPO (2020) Assessment

of Soil Functions: An Example of Meeting Competing National and International Obligations by Harnessing Regional Differences.

Front. Environ. Sci. 8:591695. doi: 10.3389/fenvs.2020.591695

\section{Assessment of Soil Functions: An Example of Meeting Competing National and International Obligations by Harnessing Regional Differences}

\author{
Kristine Valujeva1 ${ }^{1,23 *}$, Aleksejs Nipers ${ }^{2}$, Ainars Lupikis ${ }^{4}$ and Rogier P. O. Schulte ${ }^{3}$ \\ ${ }^{1}$ Department of Environmental Engineering and Water Management, Latvia University of Life Sciences and Technologies, \\ Jelgava, Latvia, ${ }^{2}$ Institute of Economics and Regional Development, Latvia University of Life Sciences and Technologies, \\ Jelgava, Latvia, ${ }^{3}$ Farming Systems Ecology Group, Wageningen University and Research, Wageningen, Netherlands, \\ ${ }^{4}$ Latvia State Forest Research Institute 'Silava', Salaspils, Latvia
}

The increased demand for bio based products worldwide provides an opportunity for Eastern European countries to increase their production in agriculture and forestry. At the same time, such economic development must be congruent with the European Union's long-term climate and biodiversity objectives. As a country that is rich in bioresources, the Latvian case study is highly relevant to many other countries especially those in Central and Eastern Europe-and faces a choice of transition pathways to meet both economic and environmental objectives. In order to assess the trade-offs between investments in the bioeconomy and the achievement of climate and biodiversity objectives, we used the Functional Land Management (FLM) framework for the quantification of the supply and demand for the primary productivity, carbon regulation and biodiversity functions. We related the supply of these three soil functions to combinations of land use and soil characteristics. The demand for the same functions were derived from European, national and regional policy objectives. Our results showed different spatial scales at which variation in demand and supply is manifested. High demand for biodiversity was associated with areas dominated by agricultural land at the local scale, while regional differences of unemployment rates and the target for GDP increases framed the demand for primary productivity. National demand for carbon regulation focused on areas dominated by forests on organic soils. We subsequently identified mismatches between the supply and demand for soil functions, and we selected spatial locations for specific land use changes and improvements in management practices to promote sustainable development of the bio-economy. Our results offer guidance to policy makers that will help them to form a national policy that will underpin management practices that are effective and tailored toward local climate conditions and national implementation pathways.

Keywords: agriculture, biodiversity, central and Eastern European countries, climate regulation, forestry, functional land management, primary productivity, soil functions 


\section{INTRODUCTION}

The increasing demand for high-quality food and fiber and the simultaneous reduction in greenhouse gas emissions is a major global challenge. Our global resources determine social and economic development, and, as such, their sustainable management increases long-term benefits. Accordingly, the United Nations formulated 17 Sustainable Development Goals, aimed at ending poverty, protecting the planet, and ensuring peace and welfare (United Nations General Assembly, 2015). Additionally, an essential objective for human beings is the transformation toward net zero emissions by increasing the sequestration capacity of soils, and by changing the technologies and raw materials of commodity production.

In the context of combatting climate change, the Paris Agreement requires each Party to define its "commitment," and submit a national implementation plan for international peerreview (UN, 2015; EU, 2018). The European Union (EU) has set a target to cut its greenhouse gas (GHG) emission levels by $43 \%$ from the Emissions Trading System (ETS) sectors and 30\% from the non-ETS sectors until 2030, compared to 2005 (EC, 2014). However, this overall target is distributed asymmetrically across Member States, depending on their economic development and the structure of their economy. The associated contemporary challenge for EU countries is to decouple emissions from production. Emission reductions are particularly challenging for the bio-economy (i.e., the agriculture and land use, land use change and forestry sectors). For instance, afforestation and wetland restoration reduce agricultural production while increasing carbon sequestration and storage, but may result in higher imports of food and feed (Eory et al., 2018).

Particularly challenging in operationalization of land use and land management planning is the reconciliation of longterm national and regional policy objectives with the myriad of strategic and tactical farm management decisions that are made by thousands of individual land managers on a daily basis. Actors in land management typically have different and sometimes contradictory views (Dingkuhn et al., 2020; Pinillos et al., 2020), which calls for an integrated approach in order to support knowledge-based decisions to link land use management at local scale and territorial planning at regional or national scale. There is a growing awareness of the need for better rural planning, protection of ecosystem services and innovative economic models to ensure environmental and socio-economic development (van Leeuwen et al., 2019). There is a growing awareness of the need for better rural planning, protection of ecosystem services and innovative economic models to ensure environmental and socio-economic development (van Leeuwen et al., 2019), and in this context, spatial information on ecosystem services or the benefits that people obtain from the ecosystems can support eligible land management decisions (de Groot et al., 2010).

Soil is the resource that underpins all of the functions that we expect from our land. It provides food, fiber, raw materials, and storage, transportation and filtration functions, as well as a platform for human activities, heritage, and a habitat and gene pool (The European Parliament, 2006). The capacity of soils to produce plant biomass is considered to be one of the most important soil functions, it is also associated to the growing demand for food security, energy and adaptation to climate change (Mueller et al., 2010). Also, the soil layers to $1 \mathrm{~m}$ depth can be either a significant sink or source of atmospheric carbon and play a major role in the global carbon budget, due to soil organic carbon degradation to inorganic forms (TaghizadehToosi and Olesen, 2016). The Communication (COM(2006) 231) of the European Commission emphasizes the importance of soil functions; however, there is currently no overarching legislative proposal for protecting soils across the EU (EC, 2006).

In this context, soil management practices represent the operationalization of land management practices (Schulte et al., 2015), and this has been captured in a number of conceptual approaches to evaluate the supply of soil-based ecosystem services (e.g., Dominati et al., 2010; Calzolari et al., 2016; Greiner et al., 2017). These conceptual approaches for classifying, quantifying and estimating soil natural capital use soil properties as the main characteristic and can be used to determine the impact of soil properties, farming practices and soil management on the provision of ecosystem services. The soilbased multifunctional framework Functional Land Management (FLM), can subsequently be used to optimize the supply of soil functions (namely primary productivity, water purification and regulation, carbon sequestration and regulation, the provision of habitats for biodiversity, and the provision and cycling of nutrients) to simultaneously meet agronomic and environmental demands (Schulte et al., 2014). Based on a literature review, Coyle et al. (2016) expanded the FLM and developed conceptual models and soil matrices to visualize the interrelationships between land use, soil type and soil functions. The pedological, physical, chemical, and biological soil properties and land use determine the ability of soils to perform the aforementioned soil functions simultaneously. The FLM approach highlights spatial mismatches between the supply and demand, and can thus be used to identify priority areas for intervention (Schulte et al., 2015). It can show synergies and trade-offs between the soil functions, allowing for the identification of interventions that maximize synergies where required (O'Sullivan et al., 2015). The European Research Project LANDMARK ${ }^{1}$ used the FLM framework to develop tools for farmers and policy makers on the sustainable management of soils by optimizing the supply of soil functions at the farm scale to provide an assessment of policies to ensure agronomic and environmental sustainability at the European scale. This current study contributes to further debates on the trade-offs between the supply of soil functions and the achievement of socio-economic and environmental objectives in two ways. First, as the original study by Coyle et al. (2016) was limited to the Atlantic climatic zone of Europe, which is dominated by grassland and livestock farming system; the current study of Latvia is chosen as a relevant Eastern European case study for quantifying the contribution of soil functions in the continental climate, which is characterized by a mosaic of cropping systems, mixed farming systems and forestry. Second, the mismatches between the demand and the supply of soil

${ }^{1}$ http://www.landmark2020.eu 
functions provides an opportunity to introduce land use changes and management practices that will ensure regional development.

The aim of our study is to identify regional opportunities for meeting national bioeconomic, climate mitigation, and biodiversity targets by assessing the spatial distribution of both the societal demands and the supply of soil functions in Latvia, as a function of land use and soil properties. The identification of the supply and the demand of soil functions spatially and the understanding of their mismatches and opportunities can provide entry points for regional land use changes and management practices to achieve national socio-economic objectives and international environmental commitments simultaneously.

\section{MATERIALS AND METHODS}

\section{Study Area}

Latvia is a country in Baltic region located in north-eastern Europe (Figure 1) where bio-based industries play a pivotal role in the economy, and it is a contemporary and highly relevant national case study for territories where these global challenges collide.

The traditional bioeconomy sectors, i.e., agriculture, forestry, fisheries, food industry, and wood industry in Latvia is 9.2\%, which is twice as high as the EU-27 average in 2017 (4.6\% of total value added). Within the bioeconomy sector, the contribution of agriculture, forestry and fishing to the bioeconomy value added is $41 \%$ in the EU and $44 \%$ in Latvia (Eurostat, 2020). A specific challenge for the sustainable development of the agriculture and forestry in Latvia, is that the expansion of the agricultural sector can cause an undesirable increase in GHG emissions and harm biodiversity, while the alternative of extending the scale of afforestation will not always give an immediate contribution to economic development. Instead, expansion of the forestry area is considered a long-term investment into the economy. For instance, one of the most common and valuable tree species Pinus Sylvestris has a rotation length of about 100 years (The Parliament of the Republic of Latvia, 2012). At the same time, the forestry sector offers significant benefits such as the local provision of habitats for biodiversity, the protection of soil

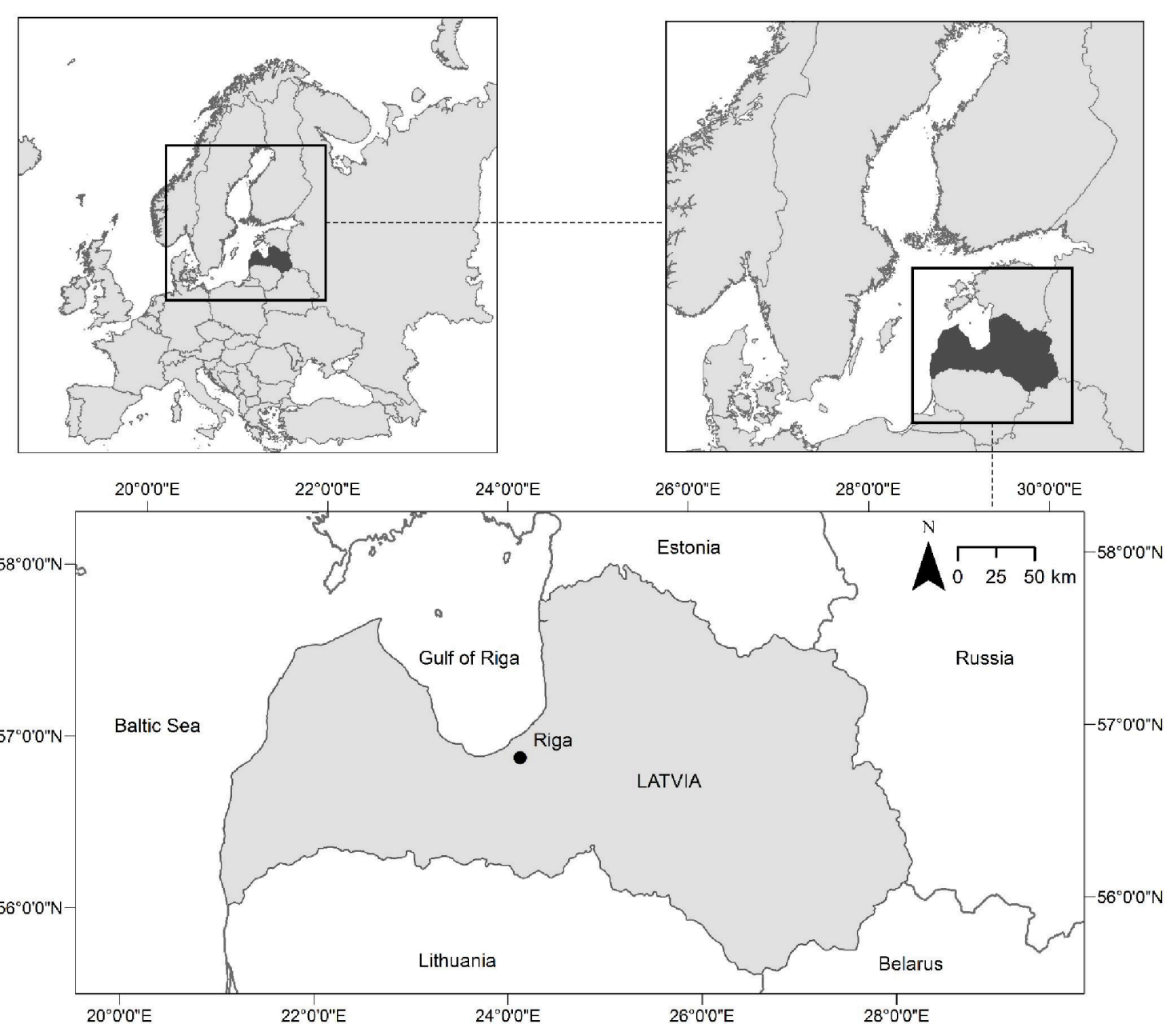

FIGURE 1 | The location of the study area. 
from erosion, the safeguarding of water and air quality and the provision of forest-based food (including wild berries and mushrooms), fiber and recreational services. Therefore, whilst the expansion of the agricultural area can give an immediate short-term boost to the economy, the expansion of forestry contributes to the achievement of long-term climate targets. These trade-offs between the short- and long-term objectives, including increased biomass production, the use of bioenergy, and carbon sequestration and storage, play an important role in scenarios for climate change mitigation. For instance, it will be challenging to meet long term climate targets while avoiding food-fuel competition without an increase in the use of bioenergy (Ekonomikas ministrija, 2018).

Another challenge that is specific to the Latvian case, and indeed to many Eastern European countries, is that its economic and agricultural activity decreased dramatically after 1990 in response to geopolitical events. As a result, agricultural activity, as well as associated GHG emissions were very low by the year 2005, which subsequently was chosen as the reference year for EU GHG policies, for reasons unrelated to the evolution of agriculture in Eastern Europe. By 2005, Latvia was slowly starting to recover its economic activities (Figure 2). Two possible way to increase production in the agricultural sector are: (1) re-using abandoned areas to expand the agricultural area or (2) producing high valueadded bioproducts. As agricultural GHG emissions are coupled to agricultural activity, this means that it is very difficult for agriculture to reach its potential for primary productivity that it had previously, without breaching EU GHG emission targets that had their baseline set at 2005 .

The quest for solutions is further complicated by the fact that climate smart land management is not the only societal demand put on our land. We also expect it to provide habitats for biodiversity, as well as to deliver on nutrient cycling, water purification and carbon sequestration (Mueller et al., 2010; Schulte et al., 2014, 2019).

\section{Generic Research Approach}

We adapted the FLM framework and selected three out of five soil functions that are most relevant to the Latvian agroenvironmental context: primary productivity, carbon regulation, and the provision of habitats for biodiversity (hereafter referred to simply as "biodiversity") (Step 1 at Figure 3 ). The two remaining soil functions that were included in the original FLM framework, i.e., water purification and the regulation and provision and cycling of nutrients, were not included in this research because of: (1) the lack of spatial data on manure at national scale and (2) the positive endorsement of good water quality in the surface water bodies in Latvia: in 2018, the annual average nitrate concentration in the surface water bodies did not exceed the limit of $11.3 \mathrm{mg}$ nitrate-N per L as defined by the EU Nitrates Directive (LVĢMC, 2018).

The FLM framework is used to assess the supply of soil functions as a function of land use and soil class, where soil class is based on the local soil property that most predominantly defines the interactions between land-based production and the environment. For instance, in Ireland the dominant soil property is the natural drainage capacity of the soil (Coyle et al., 2016), while in the Philippines and Brazil it relates to topography (Dingkuhn et al., 2020; Pinillos et al., 2020). In Latvia, organic soils are important due to the fact that organic soils can be a carbon sink or emitter, depending on land use and management practices. On the one hand, agricultural production in 2016 from organic soils was only $3.7 \%$ of the total agricultural production in Latvia (Pilvere et al., 2017), but, on the other hand, organic soils play an important role in Latvia's national emission budget, because $50 \%$ of direct $\mathrm{N}_{2} \mathrm{O}$ emissions originate from

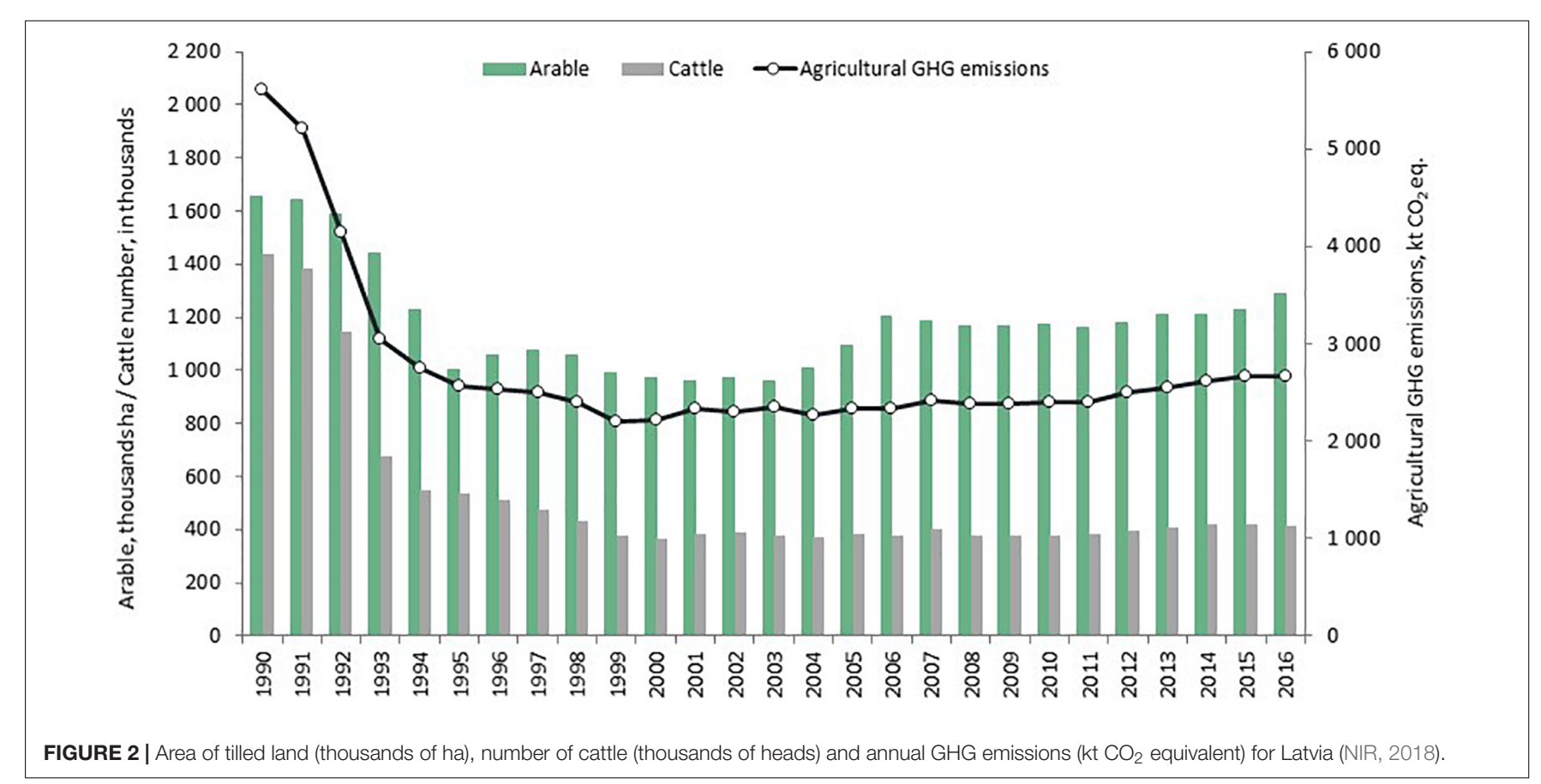




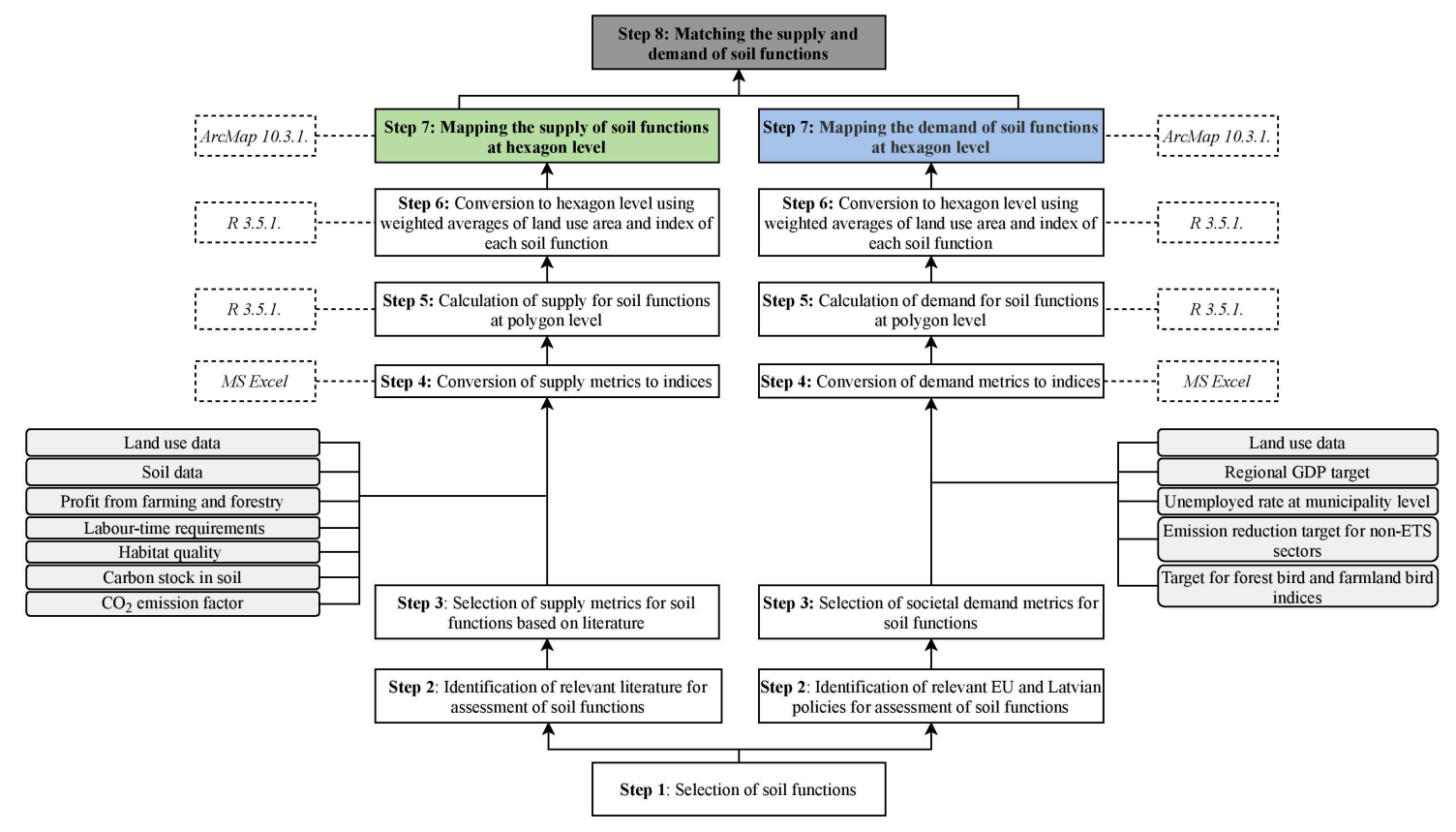

FIGURE 3 | Diagram of methodological steps followed to map the supply and demand of selected soil functions.

the management of organic soils (NIR, 2018). Therefore, for our study we chose the gradient from mineral to histic soils as the main soil property in Latvia.

An overview of the methodological steps, workflow, data used and data processing is summarized in Figure 4. We first identified the relevant literature and policy documents for assessment of soil functions (Step 2), then selected supply and demand indicators for each soil function (Step 3), converted the values of indicators to $\mathrm{z}$ scores similar to Schulte et al. (2015) to derive normalized weighting for each indicator, and applied the tabular index approach used by Greiner et al. (2018) (Step 4). The description of data and databases used to indicate the values of indicators are provided in the next sections. Then we calculated supply and demand for each soil function at polygon level in R 3.5.1 (Step 5) and generated supply and demand maps at hexagon level in ArcMap 10.3.1. by using weighted averages of land use area and index of each soil function (Figure 4) (Steps 6 and 7). Based on the balance between supply and demand for each of the functions, we aggregated the difference between supply and demand maps to identify opportunities and trade-offs between soil functions (Step 8). The detailed descriptions of the selection process of indicators and the calculation of indices are provided in the next sections and in the Supplementary Material.

\section{Land Use Data}

The total area of Latvia is $64,600 \mathrm{~km}^{2}$, with forest land and agriculture occupying $52 \%^{2}$ and $36 \%^{3}$ of total area, respectively. We derived land use data for Latvia from the project, "Evaluation of the land use optimization opportunities within the Latvian

${ }^{2} \mathrm{https}: / / \mathrm{www} \cdot \mathrm{vmd} \cdot \mathrm{gov} \cdot \mathrm{lv} / \mathrm{lv} /$

${ }^{3}$ https://www.vzd.gov.lv/lv/ climate policy framework" (funded by Joint Stock Company "Latvia's State Forests"), which has provided an in-depth socioeconomic analysis of agricultural and forestry land in Latvia (Nipers, 2019). Within this project, a database was created using the following datasets:

- An agricultural spatial dataset at scale 1:5,000 from the Rural Support Service (RSS), the Ministry of Agriculture ${ }^{4}$. This dataset shows all agricultural land polygons with detailed information of the area, crop type, and farming system held by farmers who have applied for support payments from the EU.

- A forest spatial dataset at scale 1:10,000 from the State Forest Service (SFS), the Ministry of Agriculture ${ }^{5}$. The SFS is responsible for the implementation of forest policy in Latvia. Also, it provides quality control of forest inventory data, and maintains the State Forest Register. This dataset includes detailed forest information for each inventoried forest data polygon: forest type, age of forest stand, main species in forest stand, and restrictions in forest stand.

- A land use and land holder spatial dataset at scale 1:2,000 from the State Land Service (SLS), the Ministry of Justice ${ }^{6}$. The SLS operates the National Real Estate Cadastre information system, and the spatial dataset from this system includes information about property, holder, land area, land use, value, encumbrances, buildings and their elements. Land use distribution within one property is given as a percentage of the total area of property. The

\footnotetext{
${ }^{4}$ http://www.lad.gov.lv/lv/

${ }^{5}$ http://www.vmd.gov.lv/lv/

${ }^{6}$ https://www.vzd.gov.lv/lv/
} 


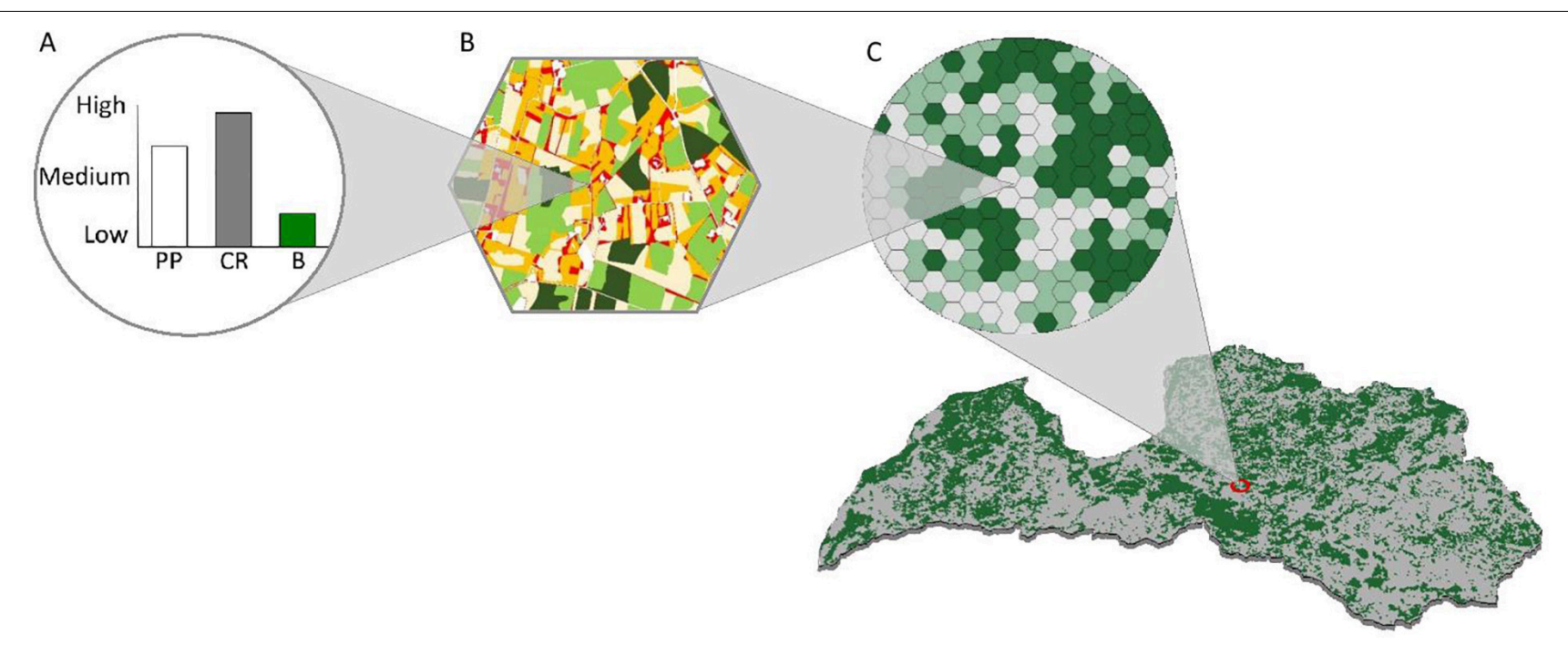

FIGURE 4 | Hierarchy of data calculation and visualization levels: (A) evaluation of supply -(B) polygon (calculation) - (C) hexagon (visualization).

polygon data from SLS was intersected with agricultural dataset to determine the abandoned agricultural land by using ArcMap 10.3.1.

- The CORINE Land Cover data base ${ }^{7}$ at scale 1:100,000 was converted from raster to polygon by using ArcMap 10.3.1., and then intersected with a forest dataset to identify spatially uninventoried forest polygons.

- A land reclamation map at scale 1:10,000 from the State Limited Liability Company "Ministry of Agriculture Real Estate". Data shows the drainage status of agricultural fields. The vector data from the land reclamation map was intersected with agricultural land polygons to find overlaps between drainage and agricultural fields to define "drained" or "not drained" status by using ArcMap 10.3.1.

The database consists of 4.4 million polygons for agricultural land use and 2.3 million polygons for forestry land use. The database is static and represents the situation in 2016. Due to the high data resolution and data processing and visualization capabilities, the territory of Latvia was subsequently divided into 68,408 hexagons of 100 ha each, as developed by Nipers (2019).

Using the aforementioned database for this study, agricultural land was divided into arable [grain, oilseed, pulses (GOP), vegetables, perennial plantations, other crops], grassland, and abandoned agricultural land. Forest land was divided into managed and natural forests. Forests which forbid economic activities, main felling, or thinning activities were classified as natural forests. Forests without restrictions, or those in which clear felling or economic activities are forbidden only during the animal reproduction season were classified as managed forests. Depending on the main wood species, managed and natural forests were subsequently subdivided into managed coniferous,

\footnotetext{
${ }^{7}$ http://map.lgia.gov.lv/

${ }^{8}$ https://www.melioracija.lv/
}

managed deciduous, natural coniferous, and natural deciduous forests (Figure 5).

\section{Soil Data}

We utilized the agricultural soil data from digitized historical soil maps at the scale 1:10,000, based on soil mapping carried out from 60 s to 80 s, to add soil type to each agricultural land polygon. Currently, this is the main agricultural soil data source

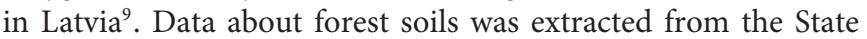
Forest Service spatial dataset at scale 1:10,000 for each forest land polygon, considering the forest type and growth conditions as main factors to determine soil type in forest land. Soil data was used to create mineral, drained organic, and organic soil classes, in accordance with the Latvian Soil Classification and the World Reference Base (WRB) for Soil Resources (IUSS Working Group WRB, 2015), with the depth of the organic layer as the main classification criterion. In the Latvian Soil Classification, the peat layer in organic soils ranges from 30 to $50 \mathrm{~cm}$ or more, corresponding to Fibric Histosols, Dystric Histic Gleysols, Hemic Histosols, Sapric Histosols and Histic Gleysols from the WRB. The mineral soil category included mineral and wet mineral soil types, which are found on artificially drained agricultural land (no organic layer) and naturally drained forest lands (organic layer less than $30 \mathrm{~cm}$ in depth). The drained organic category included artificially drained organic soils that is used for agricultural purposes (organic layer from 30 to $50 \mathrm{~cm}$ or more than $50 \mathrm{~cm}$ ) and artificially drained mineral (organic layer smaller than $20 \mathrm{~cm}$ ), as well as artificially drained organic soils (organic layer more than $20 \mathrm{~cm}$ ) that are found in forest lands. Finally, the organic soil category included soil types found in naturally wet forests which have not been affected by artificial drainage (organic layer more than $30 \mathrm{~cm}$ ). Natural bog areas and peat extraction fields were excluded from the study. Figure 6

\footnotetext{
${ }^{9}$ https://geolatvija.lv/geo/p/247
} 


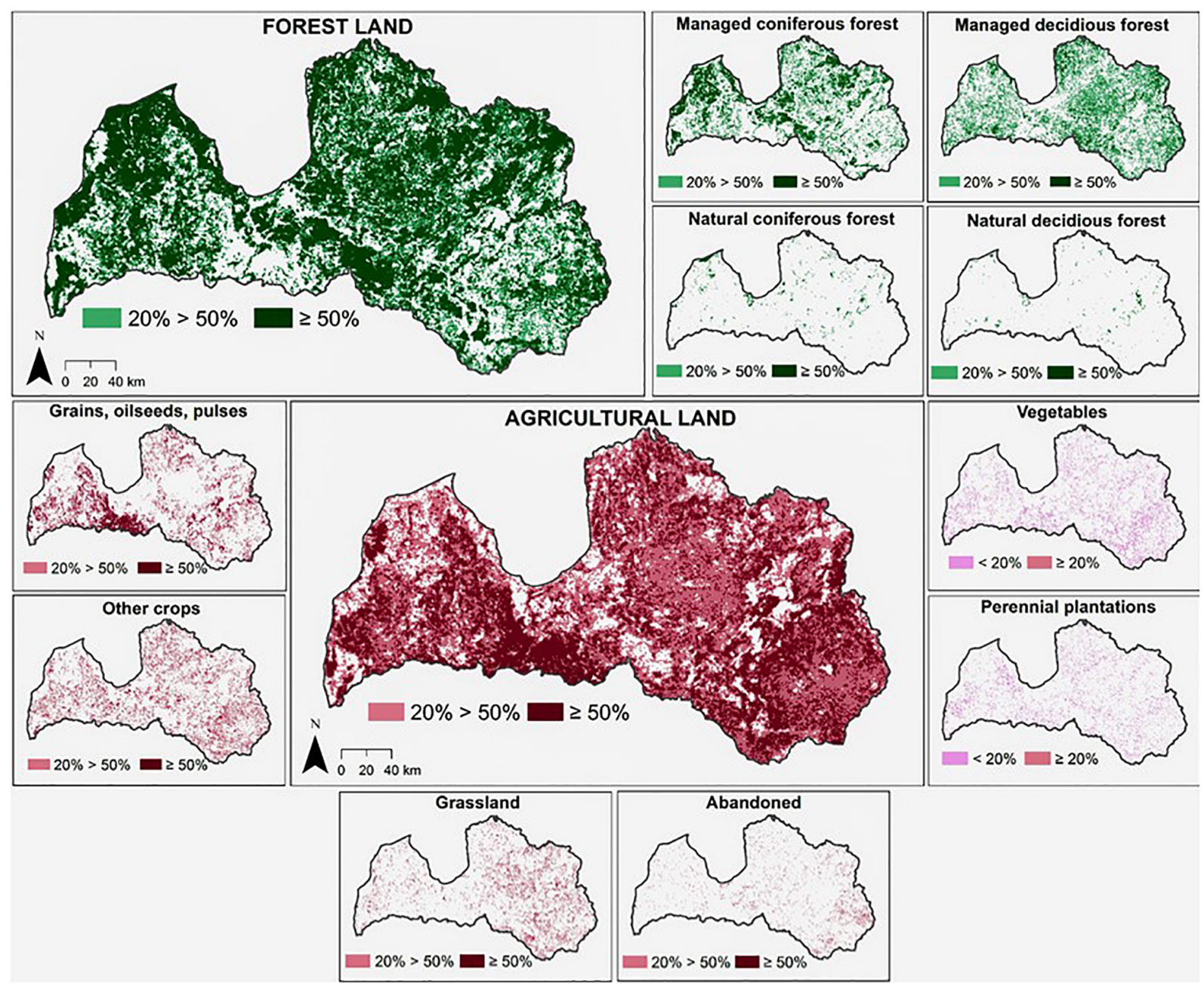

FIGURE 5 | Indicative land use map of Latvia. The percentages indicate proportional land use. For example, where forest land exceeds $50 \%$, it means that at least $50 \%$ of the hexagon area is forested (similar to O'Sullivan et al., 2015, approach).

illustrates where mineral, drained organic, and organic soils can be found in Latvia.

\section{Demand Metrics for Soil Functions}

We built on the approach of the LANDMARK project, summarized in Schulte et al. (2019), in which the demands for soil functions (or "demands on land") were derived from European policy objectives, quantified in the context of national implementation. For quantification, Schulte et al. (2019) selected demand metrics that best, albeit partially, represented the aggregate societal demand for each of the functions. We followed this approach with a similar assessment of EU and Latvian policies. We first identified the relevant policies (Figure 7) and then chose societal demand metrics for three soil functions in line with the following criteria: (1) Demand metrics must reflect the policy demands for each soil function; (2) Latvian datasets must be publicly available for each of the demand metrics; (3) Data are spatially available or could be integrated into available maps; (4) Demand metrics must allow for regional differences in Latvia to be manifested; (5) Demand metrics can be quantitatively linked to the indicators for the supply of soil functions in Latvia.

\section{Demand for Primary Productivity}

The global increase in the demand for bio-based products is allowing Latvia to once again meet its economic potential, following the radical decline in economic activities that followed the market changes in the 1990s. In response, the Latvian Bioeconomy Strategy 2030 (which is being developed in line with the National Development Plan of Latvia for 2014-2020 and the Sustainable Development Strategy of Latvia until 2030) has defined two targets associated with the primary productivity function: (1) an increase in added value from the traditional bio-economy sectors, i.e., agriculture and forestry, from EUR 2.33 billion in 2016 to EUR 3.8 billion in 2030 and (2) the provision of employment for 128,000 inhabitants. Accounting for both targets in the bio-economy sectors, we framed the demand for primary productivity by combining regional GDP targets (e.g., Development Programme of Kurzeme Planning Region 


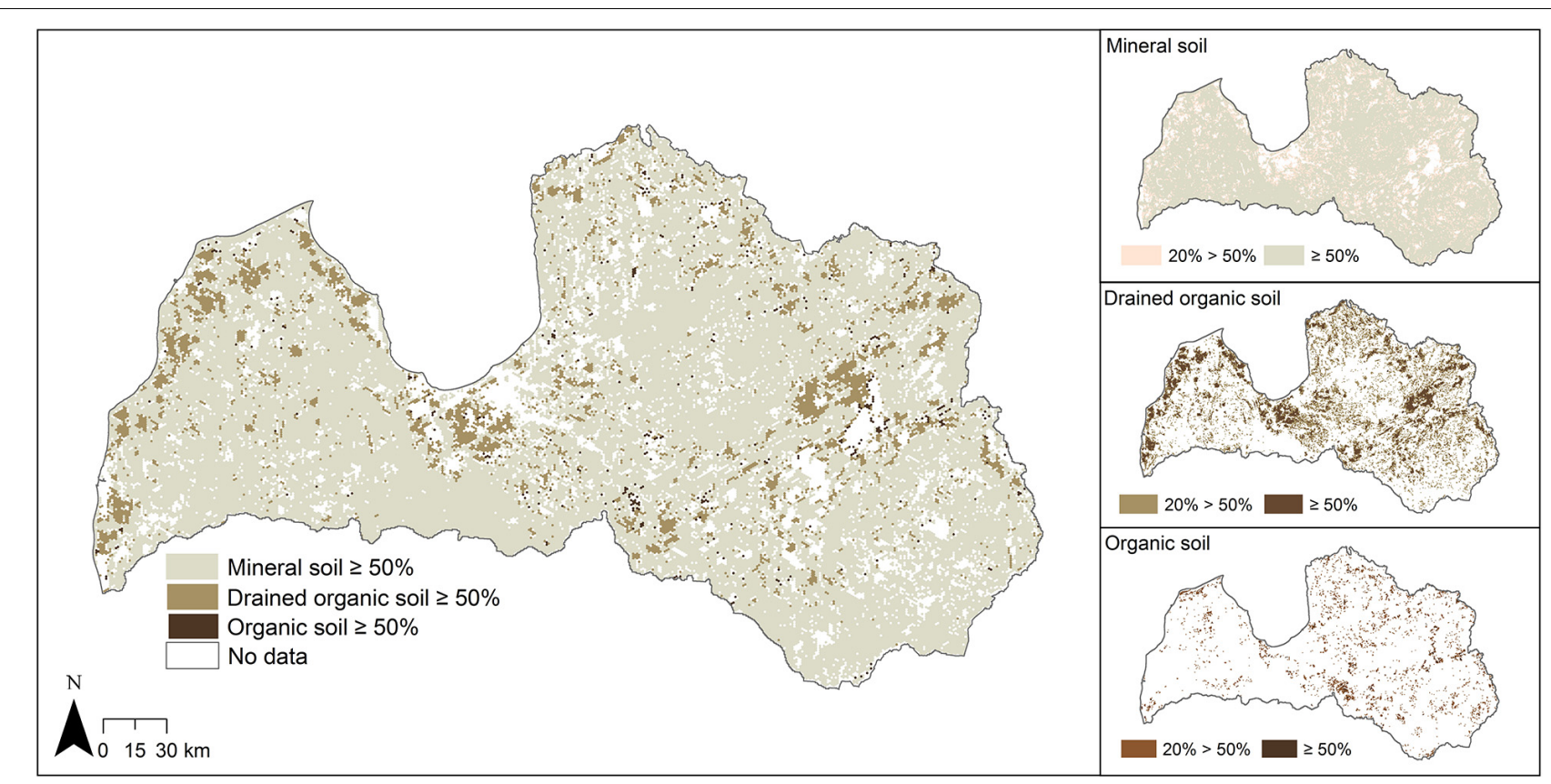

FIGURE 6 | The distribution of mineral soils, drained organic soils and organic soils in Latvia. Percentages indicate the proportional areal extent of each soil class within hexagons.

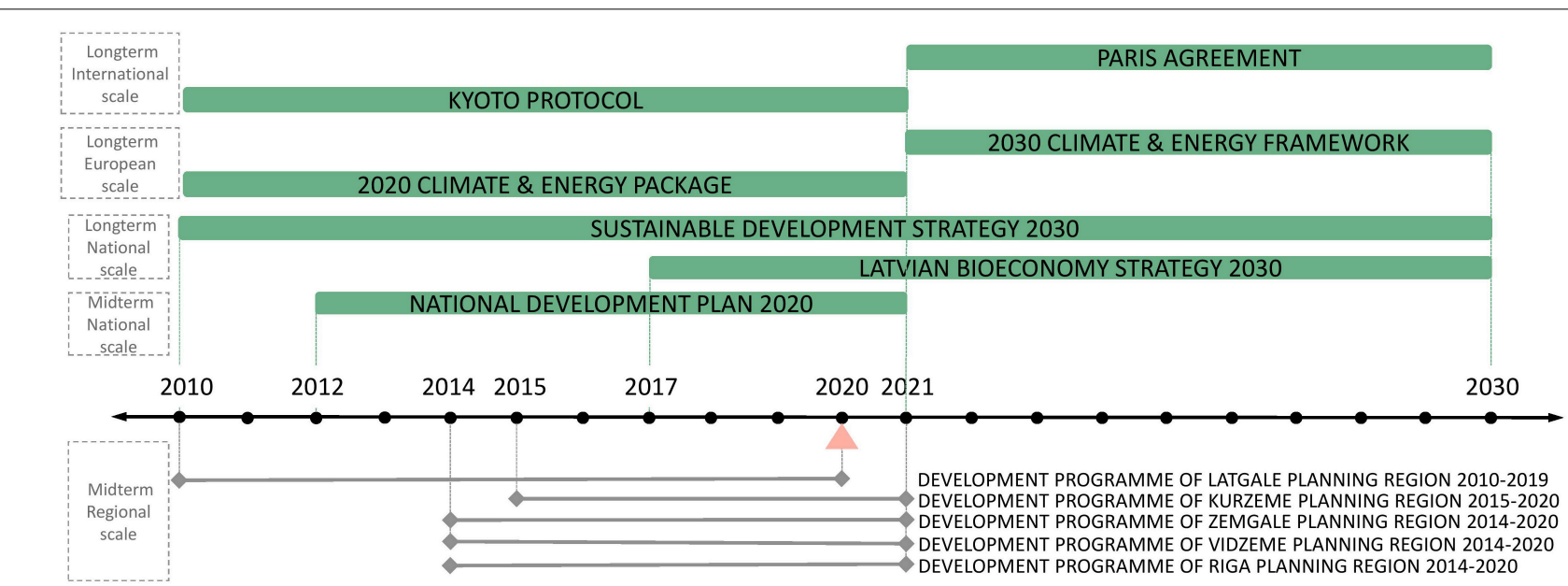

FIGURE 7 | Summary of policies used for quantification of the demand.

for 2015-2020; Development Programme of Zemgale Planning Region for 2014-2020; Development Programme of Vidzeme Planning Region for 2014-2020; Development Programme of Riga Planning Region for 2014-2020; Development Programme of Latgale Planning Region for 2014-2020) and unemployment rates at municipal level ${ }^{10}$. The Latvia-Rural Development Programme (National) 2014-2020 emphasizes agriculture and forestry as key economic sectors in rural areas that provide jobs for local people, profit for rural businesses, and taxes. Therefore, we computed a bio-economic GDP target for each region as

${ }^{10}$ https://raim.gov.lv/ a function of the projected regional compound annual growth rate, the share of agriculture, forestry and fisheries in each regional GDP, and the national added value target of bioeconomic products, divided by the area of each region. Subsequently, we applied the tabular index approach used by Greiner et al. (2018), to create one indicator for primary productivity that combines these regional GDP targets with unemployment rates at municipality level (Supplementary Tables S1, S2).

\section{Demand for Carbon Regulation}

The Paris Agreement is the most recent international agreement on mitigating climate change. The EU is participating as a 
single signatory, with its collective target asymmetrically divided between Member States as determined by their gross domestic products (GDP) per capita. The 2030 target for Latvia is a decrease in emissions for the non-ETS sectors by $6 \%$ compared to 2005 , which has not yet been allocated across the various nonETS sectors. For the period 2021-2030, each Member State can access credits from the land use sector through the so-called flexibility arrangement, subject to conditions such as the no-debit rule. This means that, for the first time in EU climate policy, carbon sequestration may be used to contribute to meeting the non-ETS target for emission reductions. The maximum level of flexibility for each Member State depends on share of emissions from agriculture; the proposed flexibility for Latvia equates to $3.6 \%{ }^{11}$ of non-ETS emissions.

\section{Demand for Biodiversity}

The EU Biodiversity Strategy, the EU Birds Directive and the EU Habitat Directive are all aimed at preserving and restoring biodiversity at European level. Whilst these policies contain very few quantitative targets, bird species richness and abundance are two factors that are well monitored and studied around Europe and that can be used as generic indicators for biodiversity (Wuczyński, 2016; Carrasco et al., 2018). Therefore, similar to Schulte et al. (2019), the societal demand for biodiversity in Latvia is framed by the targets for forest bird and farmland bird indices in the National Development Plan of Latvia for 2014-2020. The forest bird index was 96.54 in 2017, with a 2020 target of 95 by 2020. Contrastingly, the 2017 farmland bird index stood at 87.87 , with a target of 120 in 2030 . Therefore, there is a higher societal pressure on agricultural land to augment its function as a habitat for biodiversity, and farmland bird index can be used as a demand metric for quantifying the demand for the biodiversity function.

\section{Supply Metrics for Soil Functions}

We considered the gradient from mineral to histic soils and land use as the two main drivers of the supply of soil functions, namely primary productivity, carbon regulation and biodiversity, in Latvia. We also identified relevant supply metrics for three soil functions that were in line with the following criteria: (1) Supply metrics must reflect the present situation in Latvia for each soil function; (2) Latvian datasets must be publicly available for each of the supply metrics; (3) Data are spatially available or could be integrated into available maps; (4) Supply metrics must be capable of showing regional differences in Latvia; (5) Supply metrics can be quantitatively linked to the indicators for the demand of soil functions in Latvia.

\section{Supply of Primary Productivity}

Biomass production is determined by soil properties, climatic conditions, and management practices. Under optimal crop nutrient conditions, these interactions are mediated through the plant-available water dynamics of the soil. Lower crop yields are observed both when either the amount of available water in the soil is low or when the soil is subject to saturation (e.g., Schulte et al., 2012; Coyle et al., 2016; Bölenius et al., 2017). As a result,

\footnotetext{
${ }^{11}$ https://ec.europa.eu/clima/policies/effort/proposal_en
}

yields tend to be higher in mineral soils compared to organic soils. In Latvia, the average annual precipitation is $703 \mathrm{~mm}$, which exceeds annual evaporation by $245 \mathrm{~mm}$ on average (LVGMC, 2017). Transient waterlogging has a negative impact on crop yields, caused by limited root development and $\mathrm{N}$ loss due to denitrification and leaching (Zhang et al., 2006; Jiang et al., 2008). In forestry systems, too, tree growth is disturbed in areas with a high water table (Frelechoux et al., 2000; Zalitis and Indriksons, 2009; Cedro and Lamentowicz, 2011). As a result of a high water level and a lack of oxygen and nutrients, the decomposition of organic matter is inhibited and thus carbon rich soils are formed. As a result, opportunities for intensive agricultural or forestry activities are severely limited in the absence of artificial drainage.

The aforementioned factors impact on profits from farming and forestry, and the labor-time requirements. Therefore, we combined the indices of profit and employment, using the tabular index approach by Greiner et al. (2018) to derive one integrated societal supply metric for primary productivity (Supplementary Tables S3, S4). Calculations of profit and employment were taken from Nipers (2019).

The economic component of the index is profit. The calculations for profit are similar for both agriculture and forestry, and ultimately computed as incomes from sold produce plus subsidies minus production costs (including amortization). Subsidies are significant for Latvian farmers, especially for medium and small farmers whose livelihood depends on subsidies due to price fluctuations and unusual weather conditions. Subsidies for forestry were assumed to be zero. Unlike in agriculture, forestry investments are long-term and profits only occur during harvesting, which takes place 24 times during the rotation period of a stand (sometimes up to 100 years). In each forest stand, four different timber assortments may be produced during harvesting, each with a different price. Costs were computed as: the sum of stand regeneration and management costs after final felling, harvesting costs from final felling and thinning, administrative costs, and costs to maintain infrastructure (forest roads and drainage systems). Stand regeneration and management costs are expressed in per ha units and occur only after final felling, while harvesting costs are expressed as a product of total harvesting volume, and harvesting costs per $1 \mathrm{~m}^{3}$ volume and are occurring both in final felling and thinning. Administrative and infrastructure maintenance costs are assumed to be EUR 43.6 per ha for all of the forest stands, equating to the average value in 2017 that is provided by State Forest Service. Profit is calculated as euro per ha per year.

The social component of the index is employment. Employment was evaluated as a labor-time contribution which is expressed in working hours per ha. Working hours are calculated as a function of crop or forest type and farm size. For instance, wheat production on large farms requires $15 \mathrm{~h}$ of labor per ha (Nipers, 2019).

\section{Supply of Carbon Regulation}

Soil organic carbon (SOC) is a key indicator for soil quality; it affects nutrient cycling, pesticide and water retention, and soil structure maintenance (Karlen et al., 1997; Mueller et al., 2010). Soil biota, including bacteria, fungi, plant roots and other soil 
organisms, regulate the decomposition process of residues in soil and carbon sequestration in aggregates (Blanco-Canqui and Lal, 2004). In this context, soils play a pivotal role in regulating global carbon fluxes. In Northern and Central European countries, the use of drained organic soils for agricultural purposes has contributed significantly to GHG emissions (Kløve et al., 2017). Therefore, reducing emissions from these areas is one of the main emission reduction measures that are available to the combined agricultural and land use, land use change and forestry (LULUCF) sectors.

Both the total carbon stock in soils and change thereof are important metrics in determining the capacity of a soil to contribute to carbon regulation. Therefore, for our evaluation of the climate regulation function, we combined soil carbon stock values from national studies with $\mathrm{CO}_{2}$ emission factors for drained organic soils from the IPCC Wetlands Supplement 2013. The $\mathrm{CO}_{2}$ emission factor was developed in line with the observation that in drained organic soils, $\mathrm{CO}_{2}$ is emitted as long as soil is being drained or organic matter remains (IPCC, 2014). The values were combined to create one metric, again using the tabular index approach by Greiner et al. (2018) (Supplementary Tables S5, S6). Carbon stock values in agricultural land were obtained from a Latvian national study where organic carbon was evaluated in different soil types, including mineral and organic soil types, in cropland and grassland with no changes in land use for at least 20 years. In this study, data from 218 plots were used to calculate an average organic carbon stock for each soil and land use combination. In mineral soils, the organic carbon stock at 0 $40 \mathrm{~cm}$ depth amounted to $83.9 \pm 7.1 \mathrm{t} \mathrm{ha}^{-1} \mathrm{C}$ and $89.4 \pm 12.0$ $\mathrm{t} \mathrm{ha}^{-1} \mathrm{C}$ for cropland and grassland soils, respectively, while in organic soils, these were higher at $122.0 \pm 45.2 \mathrm{t} \mathrm{ha}^{-1} \mathrm{C}$ in cropland and $208.2 \pm 22.9 \mathrm{t} \mathrm{ha}^{-1} \mathrm{C}$ in grassland (Bardule et al., 2017). The average carbon stock was $97.8 \pm 14.7 \mathrm{t} \mathrm{ha}^{-1} \mathrm{C}$ in afforested agricultural land (Lazdinš̌ et al., 2015) and $268.5 \mathrm{t} \mathrm{ha}^{-1}$ C in afforested organic soils (Lazdins et al., 2014). Carbon stock values for forest soils were obtained from the joint international demonstration project BioSoil. Data from 475 soil samples (that were collected from 95 monitoring plots at $0-40 \mathrm{~cm}$ depth across the country) were used to calculate carbon stock in forest soils. Carbon stocks ranged from $99.06 \mathrm{t} \mathrm{ha}^{-1} \mathrm{C}$ in managed coniferous forests on mineral soil to $289.56 \mathrm{t} \mathrm{ha}^{-1} \mathrm{C}$ in managed deciduous forests on organic soil.

\section{Supply of Biodiversity}

The abundance of microbial communities in soil depends on soil $\mathrm{pH}, \mathrm{C}: \mathrm{N}$ ratio, and concentrations of calcium and aluminum cations (Thomson et al., 2015), and additionally interacts with soil management; for instance, less frequent tillage in grasslands results in higher biomass production in the root system and a higher soil food web diversity (Tsiafouli et al., 2015). High input agriculture, unsustainable forestry practices, and land use intensification lead to a decrease in biodiversity and ecosystem service delivery (de Ruiter and Brown, 2007; Sylvain and Wall, 2011; Wagg et al., 2014). In addition, land use changes from permanent grassland and extensively managed land to annual crop rotations is the main cause of soil biodiversity loss because of the strong and consistent effect on the structure of soil food web (de Vries et al., 2013).

However, due to the lack of coherent national and EU census data, it is not possible to evaluate soil biodiversity by using genetic or species diversity; therefore, within this study, the biodiversity function is evaluated as the quality of habitats for birds at field level. Schulte et al. (2019) also concluded that farmland birds are the only available indicator for measuring the diversity and integrity of habitats at European scale. Ernst et al. (2017) found a strong relationship between farmland and woodland management status (managed versus abandoned) and bird species' richness and abundance in agriculture and forest dominated landscapes. Landscape diversity is a strong driver for the habitat quality for farmland and non-farmland birds, and refers to a mosaic of arable land, forest land and field margins with scrubs (Wuczyński, 2016; Pedersen and Krøgli, 2017; Zingg et al., 2018; Bretagnolle et al., 2019). Accordingly, we divided the landscape in Latvia into three types: heterogeneous landscapes, homogeneous arable ( $>70 \%$ of hexagon is arable) and homogeneous forest ( $>70 \%$ of hexagon is forest).

We derived indices for habitat quality from the relationships between habitat quality and land use intensity in the EU (Reidsma et al., 2006) with a maximum value of 10 , which indicates a very good habitat quality with high potential for biodiversity, and a minimum value of 1 , which indicates poor habitat quality. Land use intensity is characterized by discernment of organic and conventional farming systems. Intensification of agriculture decreases habitat quality with biodiversity scoring $34 \%$ higher in organic farming systems compared to conventional farming systems (Tuck et al., 2014). Therefore, arable fields in homogeneous landscapes with conventional farming practices were assigned index 1, whereas arable fields in homogenous landscape with organic farming practices were scored as 4. Higher habitat quality is attributed to fields located in heterogeneous landscapes. A reduction in land abandonment and the maintenance of landscape heterogeneity leads to improved farmland and non-farmland bird populations (Pedersen and Krøgli, 2017), and as such, the index for extensively managed grasslands in heterogeneous landscapes was ranked as 10 in line with Dickie et al. (2011) and Tsiafouli et al. (2015). Similar to agricultural land, there are no available data for evaluation of biodiversity in forest soils; therefore, biodiversity was evaluated as a habitat quality for birds depending on management intensity, forest stand age and dominant species (Supplementary Tables S7-S10).

\section{RESULTS}

\section{Demand for Soil Functions}

The demand maps for the three soil functions, namely primary productivity, carbon regulation and biodiversity, demonstrate the different spatial scales at which variation in demand is manifested; from the local scale (biodiversity) to regional scale (primary productivity) and national scale (carbon regulation).

A higher demand for primary productivity function is found in municipalities in which higher unemployment 
rates co-occur with higher targets for GDP growth (Figure 8). The south-eastern region has the highest demand of all regions in Latvia. In northern Latvia, and in the north central part of Latvia, the demand for primary productivity is lower, reflecting lower unemployment rates and more modest requirements for further economic growth.

Similar to Schulte et al. (2015) and Pinillos et al. (2020), the demand for carbon regulation is evenly spread at the national level, reflecting the absence of sector-specific targeting between the non-ETS sectors such as housing, agriculture, waste and transport (Figure 8). This inference was made because it is currently yet unknown which production sectors and land uses will be affected by the emission reduction target set by the Paris Agreement.

The demand for the augmentation of biodiversity is highest in areas dominated by agricultural land (Figure 8), most obviously in hexagons where agricultural land occupies more than $75 \%$ of the area. Demand is proportionally lower in hexagons dominated by other land uses in which the Bird Index is currently already meeting its 2030 targets.

\section{Supply of Soil Functions}

The right column in Figure 8 shows the spatial patterns of the supply of soil functions in relation to land use and soil organic carbon characteristics.

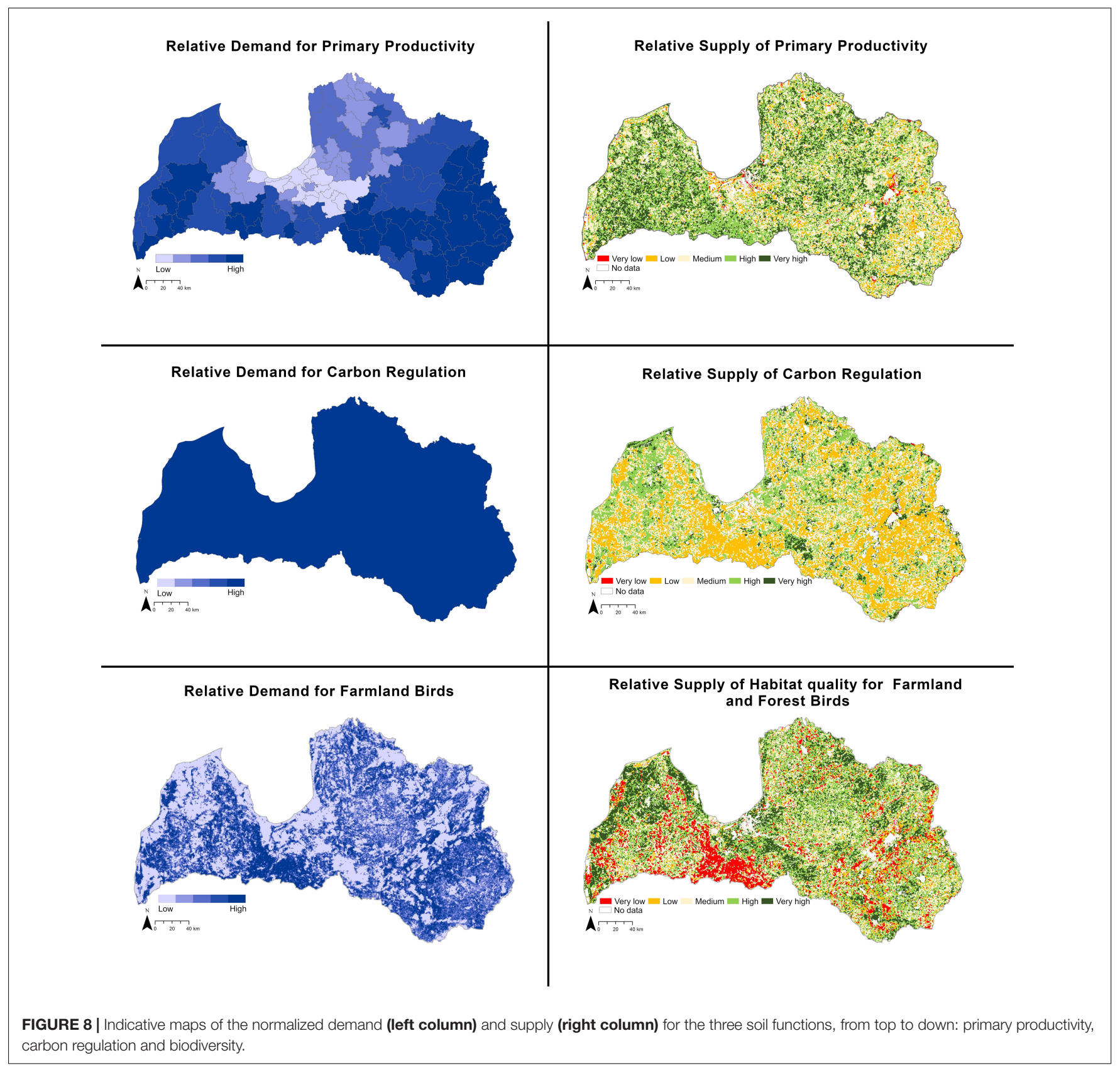


The supply of primary productivity is highest in managed agricultural land areas, specifically in the central part of Latvia and the western region. A medium supply can be found in forests on mineral and wet mineral and drained organic soils. Low and very low supplies are found in abandoned areas, as well as in natural forests and managed forests on organic soils (Figure 8).

The supply of the carbon regulation function ranges from low to very high across the country (Figure 8): the central parts of Latvia and the south-eastern region show lower supplies of the carbon regulation compared to other regions. The western part of Latvia shows a higher supply, while the north-eastern region shows a medium supply compared to other regions. Locations with a very high supply are located in the central part of the south-eastern region of Latvia, in the northern part of the western region, and in the center of the north-eastern region.

Very low supplies of the biodiversity function are found in highly intensive agricultural land use areas located in homogeneous landscapes (e.g., the central part of Latvia), in natural forests with young and middle age stands and also in managed forests, in forest clearance areas, and middle age and seasoning age managed forests with white alder as the main tree species. In extensive grasslands, abandoned areas, and extensively managed areas located in heterogeneous landscapes, the supply of biodiversity function is high, and also in over-seasoned and maturity natural forest stands and in young and over-seasoned managed forest stands (Figure 8).

\section{Matching Supply and Demand for Soil Functions}

Based on the balance between supply and demand for each of the functions, we aggregated the difference between the supply and demand maps in Figure 8, into nine regions (Figure 9) that correspond to Pilvere et al. (2015), who distinguished 14 regions to highlight the main territorial differences. Region 2 and 5 combines multiple regions from Pilvere et al. (2015), because those areas show similarities in supply and demand of soil functions.

Each region presented in Figure 9 has a specific balance between the supply and demand for the three soil functions, and hence a specific requirement for land use changes or improvements in management practices, with a view to matching the supply of soil functions with regional demands.

\section{DISCUSSION}

\section{Pathways to Match Supply and Demand of Soil Functions}

Our results make explicit the discrepancies between the demand and supply of soil functions, the latter being determined by the gradient from mineral to histic soils as the main soil property and the land use. Our analysis has two implications for land managers and policy makers alike. Firstly, it underscores the notion that it may not only be difficult, but also not necessary nor desirable to try and maximize all soil functions everywhere; instead, the spatial variation in the demand and supply of soil functions calls for an optimization, rather than maximization, of soil functions. As part of a large-scale European monitoring exercise of the LANDMARK project, Zwetsloot et al. (2020) showed that it is virtually impossible for individual land managers to maximize all five soil functions simultaneously, as a result of trade-offs between the response of the soil functions to land management practices. However, the same date shows that it is feasible for most farmers to simultaneously optimize at least three soil functions on each farm, to meet functional and societal demands as defined by Schulte et al. (2019). Thus, a regional approach allows for a more realistic optimization of soil functions, and can thus contribute to the successful operationalization of policy ambitions. While the LANDMARK project (Schulte et al., 2019; Vrebos et al., 2020) recently demonstrated the need for a differentiated approach

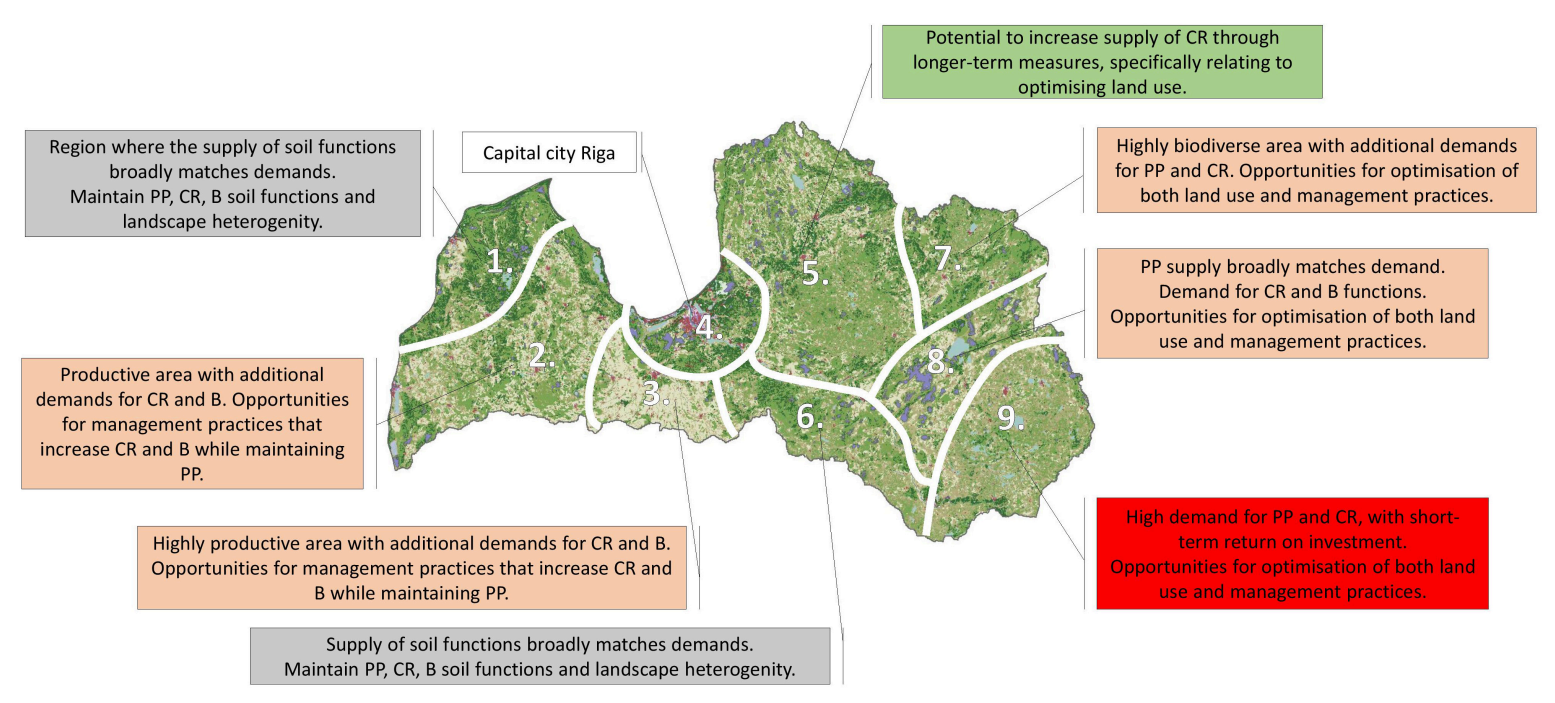

FIGURE 9 | Indicative map showing geographical areas of relevance to soil functions and where application of land use changes or changes in management practices from Table 1 are applicable (PP, primary productivity; CR, carbon regulation; B, biodiversity). 
between EU Member States, our current study goes further and illustrates the need for sub-national differentiation of land management planning.

Secondly, there are two possible ways to such regional optimization: targeted land use change and the introduction of management practices (Schulte et al., 2014): indeed, Dingkuhn et al. (2020) concluded that the combination of land use system and management strategies is necessary to reach sustainability in agricultural resource-use. This duality requires an integrated approach to land use planning and the targeted incentivization of land management practices and therefore close cooperation between the stakeholders and the delivery of essential soil functions from the local to the landscape scale and at the national level. Such management of soil functions from farm to national scale to achieve current and future socio-economic and environmental goals is a key challenge for policy makers (Valujeva et al., 2016). One option is to provide targeted incentives to farmers to introduce new management practices or to improve existing management practices in order to jointly achieve national targets through knowledge transfer and financial resources.

In this context, the Latvian Bio-economy Strategy 2030 was developed to guide the development for the traditional bioeconomic sectors (LIBRA2030, 2017). This strategy must be taken into consideration in the development of future Latvian planning documents. Such planning documents for territorial development were developed several years ago and ideally should complement each other. However, in reality there is no clear measurable connection between targets in planning documents; as a result, they do not give a comprehensive vision of the desired direction for development of the bio-economy. Therefore, it is not possible to evaluate how short-term targets at regional scale improve long-term targets at national scale. For instance, each region in Latvia has specified targets that relate to our soil functions, such as GDP increase, the preservation of agricultural and forestry land use and even targeted declines in GHG emissions in some regions. However, thus far there has been no assessment of whether, and to what extent, these targets will contribute to the achievement of national targets or even international commitments. Here, we exemplify how purposeful regional differentiation in land management practices can be effective in meeting the demand for soil functions at regional level and thus deliver on aggregate commitments at national level.

\section{Improvements in the Supply of Soil Functions}

Changes in land use and land management practices that aim to selectively increase one of the soil functions are associated with the aforementioned trade-offs with the other soil functions. Here, we exemplify this with 17 management practices selected from the literature (referenced in Table 1) that are applicable for the temperate climate zone and that positively or neutrally affect the selected soil functions. In Table 1, we evaluate the percentage difference of supply of soil functions before and after the implementation of management practices, derived from these studies, illustrating the trade-offs between increasing primary productivity, promoting carbon sequestration and ensuring biodiversity, and accordingly, the need for close cooperation and knowledge transfer between land managers and policy makers to accomplish the desired changes. For example, extensification of grassland can increase the supply of the carbon regulation function due to increases in carbon stocks and a decrease in GHG emissions but at the expense of primary production, while intensification may result in the reverse trade-off. At the same time the maintenance or improvement of soil properties can also lead to higher primary productivity without a reduction in the supply of other soil functions (Taghizadeh-Toosi and Olesen, 2016; Bharali et al., 2017). For example, many studies have investigated the potential to increase the carbon stock in the agricultural landscape by creating a new biomass stock for the capture of $\mathrm{CO}_{2}$ from the atmosphere (Mäkiranta et al., 2007; Weslien et al., 2009; Fortier et al., 2015; TaghizadehToosi and Olesen, 2016). Carbon sequestration at farm level can be promoted by changes in farm management, such as highprecision management of resources, minimum or no tillage, and the diversification of crop types (de Ruiter and Brown, 2007; Nielsen et al., 2015). The impact on other functions, however, must be considered before instigating such changes.

Landscape diversity is the main factor for biodiversity (Wuczyński, 2016; Pedersen and Krøgli, 2017; Zingg et al., 2018; Bretagnolle et al., 2019) and even small changes in land use at the farm scale can decrease the provision of biodiversity at the landscape scale. One of the key changes that can improve the supply of the biodiversity function is extensive land management, for example through land use change from arable to grassland (Taghizadeh-Toosi and Olesen, 2016) or through the introduction of minimum or no-till management and diversification (Nielsen et al., 2015). This diversity of potential trade-offs and synergies necessitates the implementation of smart land management in accordance to medium-term and longterm targets.

\section{Regionalized Approaches to Sustainable Land Management}

A high demand for primary productivity and carbon regulation function with short-term returns on investments is evident in region 9 . Here, management practices number $1,2,5,6,9,13,15$, and 16 from Table 1 could prove most effective. Region 5 has high potential to become a carbon sink and contribute to long-term commitments trough optimization of land use, and therefore management practices number 1, 2, 3, and 4 are applicable in this region. Management practices number 6, 10, and 13 are suitable for regions 2 and 3, where supply of primary productivity broadly meets demand, but where additional demands are placed to deliver on the carbon regulation function and biodiversity; in region 8 , management practice number 2 can also be applicable. In the highly biodiverse region 7 , management practices $1,2,5,6$, 13,15 , and 16 may increase the supply of primary productivity and the carbon regulation function, without unduly affecting the biodiversity function. In regions 1 and 6 , the supply of soil functions broadly matched demand, therefore management practice number 7 (which aims to maintain supply of primary 
TABLE 1 | List of possible management practices ( $\uparrow$-increase; $\downarrow$-decrease; $\rightarrow$-do not affect).

\begin{tabular}{|c|c|c|c|c|c|}
\hline \multicolumn{2}{|c|}{ Management practice } & \multirow[t]{2}{*}{ Primary productivity } & \multirow{2}{*}{$\begin{array}{l}\text { Carbon } \\
\text { sequestration }\end{array}$} & \multirow[t]{2}{*}{ Biodiversity } & \multirow[t]{2}{*}{ References } \\
\hline & Land use change & & & & \\
\hline 1. & $\begin{array}{l}\text { Afforestation of fertile well-drained organic } \\
\text { soils }\end{array}$ & $452 \% \uparrow$ & $69 \% \uparrow$ & $0 \% \rightarrow$ & $\begin{array}{l}\text { Minkkinen et al., 1999; Weslien et al., 2009; } \\
\text { Schrier-Uijl et al., } 2014\end{array}$ \\
\hline 2. & Afforestation of organic soil & $73 \% \uparrow$ & $50 \% \uparrow$ & $4 \% \uparrow$ & $\begin{array}{l}\text { Minkkinen et al., 1999; Mäkiranta et al., } \\
\text { 2007; Ausec et al., 2009; Maljanen et al., } \\
2010\end{array}$ \\
\hline 3. & $\begin{array}{l}\text { Conversion of some of the current annual } \\
\text { crops to grassland }\end{array}$ & $38 \% \downarrow$ & $25 \% \uparrow$ & $68 \% \uparrow$ & $\begin{array}{l}\text { West and Post, 2002; Poeplau et al., 2011; } \\
\text { Taghizadeh-Toosi and Olesen, 2016; } \\
\text { Gosling et al., } 2017\end{array}$ \\
\hline \multirow[t]{2}{*}{4.} & $\begin{array}{l}\text { Rewetting organic soils under grassland } \\
\text { leads to these ecosystems becoming } \\
\text { neutral or small C sinks }\end{array}$ & $20 \% \downarrow$ & $96 \% \uparrow$ & $0 \% \rightarrow$ & $\begin{array}{l}\text { Remm et al., 2013; Maanavilja et al., 2015; } \\
\text { Karki et al., 2016; Renou-Wilson et al., } \\
2016\end{array}$ \\
\hline & Farm management & & & & \\
\hline 5. & $\begin{array}{l}\text { Use of farmyard manure and green } \\
\text { manures along with returning crop residues }\end{array}$ & $20 \% \uparrow$ & $16 \% \uparrow$ & $0 \% \rightarrow$ & $\begin{array}{l}\text { Taghizadeh-Toosi and Olesen, 2016; } \\
\text { Bharali et al., } 2017\end{array}$ \\
\hline 6. & $\begin{array}{l}\text { No-till increases fungal biomass in general, } \\
\text { which leads to improved soil structure that } \\
\text { increases infiltration and reduces erosion }\end{array}$ & $2.6 \% \uparrow$ & $10 \% \uparrow$ & $21 \% \uparrow$ & $\begin{array}{l}\text { Ogle et al., 2005; Simpson et al., 2010; Van } \\
\text { den Putte et al., 2010; Nielsen et al., 2015; } \\
\text { Martínez et al., } 2016\end{array}$ \\
\hline 7. & Preserve existing C stocks in soils & $0 \% \rightarrow$ & $0 \% \rightarrow$ & $0 \% \rightarrow$ & Renou-Wilson et al., 2016 \\
\hline 8. & $\begin{array}{l}\text { Short rotation plantation in riparian } \\
\text { ecosystems on rich organic soil with } \\
\text { periodical harvest }\end{array}$ & $17 \% \uparrow$ & $3 \% \uparrow$ & $35 \% \downarrow$ & $\begin{array}{l}\text { Laganière et al., 2010; Dimitriou and } \\
\text { Dominik, 2015; Strazdinsa, 2015; } \\
\text { Hénault-Ethier et al., } 2017\end{array}$ \\
\hline 9. & $\begin{array}{l}\text { High-precision management of nutrients, } \\
\text { chemistry, water, pests, and pathogens }\end{array}$ & $27 \% \uparrow$ & $\begin{array}{l}0 \% \rightarrow \text { No change } \\
\text { because no } \\
\text { evidence }\end{array}$ & $\begin{array}{l}0 \% \rightarrow \text { No change } \\
\text { because no } \\
\text { evidence }\end{array}$ & Hedley, 2015; Nielsen et al., 2015 \\
\hline 10. & $\begin{array}{l}\text { Minimum tillage with residue retention and } \\
\text { use of green manure }\end{array}$ & $5 \% \downarrow$ & $3 \% \uparrow$ & $6 \% \uparrow$ & $\begin{array}{l}\text { Chan, 2001; Ogle et al., 2005; Van den } \\
\text { Putte et al., 2010; Nielsen et al., } 2015\end{array}$ \\
\hline 11. & $\begin{array}{l}\text { No-tillage leads to increase in species } \\
\text { richness and overall density }\end{array}$ & $9 \% \downarrow$ & $10 \% \uparrow$ & $21 \% \uparrow$ & de Ruiter and Brown, 2007 \\
\hline 12. & $\begin{array}{l}\text { Reed canary grass as a bioenergy crop on } \\
\text { organic soils }\end{array}$ & $20 \% \downarrow$ & $45 \% \uparrow$ & $23 \% \uparrow$ & $\begin{array}{l}\text { Shurpali et al., 2009; Tavi et al., 2010; } \\
\text { Mander et al., 2012; Karki et al., } 2016\end{array}$ \\
\hline 13. & $\begin{array}{l}\text { Diversification of crop types, permanent } \\
\text { plant cover, buffer strips }\end{array}$ & $10 \% \uparrow$ & $4 \% \uparrow$ & $23 \% \uparrow$ & $\begin{array}{l}\text { McDaniel et al., 2014; Nielsen et al., 2015; } \\
\text { Zuber et al., 2015; Osterholz et al., } 2018\end{array}$ \\
\hline 14. & $\begin{array}{l}\text { Improved grassland management through } \\
\text { extensive grazing }\end{array}$ & $55 \% \downarrow$ & $7.7 \% \uparrow$ & $128 \% \uparrow$ & $\begin{array}{l}\text { Conant et al., 2001; Renou-Wilson et al., } \\
\text { 2016; Van Vooren et al., } 2018\end{array}$ \\
\hline 15. & $\begin{array}{l}\text { Increase groundwater level on organic soils } \\
\text { for shallow rooting vegetable production }\end{array}$ & $7 \% \uparrow$ & $31 \% \uparrow$ & $\begin{array}{l}0 \% \rightarrow \text { No change } \\
\text { because no } \\
\text { evidence }\end{array}$ & $\begin{array}{l}\text { Berglund and Berglund, 2010; Weslien } \\
\text { et al., 2012; Musarika et al., 2017; Matysek } \\
\text { et al., } 2019\end{array}$ \\
\hline 16. & $\begin{array}{l}\text { Application of organic amendments in } \\
\text { combination with inorganics in wheat } \\
\text { cropping system }\end{array}$ & $20 \% \uparrow$ & $51 \% \uparrow$ & $0 \% \rightarrow$ & Bharali et al., 2017 \\
\hline 17. & $\begin{array}{l}\text { Water table management on organic soil } \\
\text { (keep it stable) }\end{array}$ & $19 \% \downarrow$ & $31 \% \uparrow$ & $0 \% \rightarrow$ & Leppelt et al., 2014; Matysek et al., 2019 \\
\hline
\end{tabular}

productivity, the carbon regulation function and biodiversity) is most applicable in these regions, along with the maintenance of heterogeneity of the landscape.

\section{Limitations}

In our research, the selection of proxy indicators for quantifying supply and demand of soil functions strongly depends on available data which must be considered in the interpretation of results.

The demand for carbon regulation is framed at the national level without highlighting specific areas for intervention; as a result, the demand for carbon regulation function has not yet reached local levels of administration. At the same time, the $6 \%$ reduction target proposed by the EU Climate and Energy Framework 2030 will affect bioeconomics in Latvia: most likely, all non-ETS sectors will have to contribute to achieving the long term climate target. For the supply of the carbon regulation function, we only included carbon stocks in soil because of the national data availability, and did not include aboveground and belowground biomass, both of which also play an important role in carbon budget. Soil is the largest terrestrial carbon stock, and it stores approximately three times more carbon than the atmosphere and vegetation (Ramesh et al., 2019). The importance of sequestering carbon into agricultural soils also 
has been emphasized at the European scale, because those soils have high potential to reduce GHG emissions and at the same time to improve soil quality which gives benefit to farmers (Meredith, 2019).

We assessed the supply of biodiversity using habitat quality for bird species' richness and abundance and land use; indeed, habitat changes due to land use change are considered as one of the major drivers for the decline in global biodiversity (De Baan et al., 2013). Nevertheless, biodiversity has many dimensions at genetic, species and ecosystem level including abundance of microbial communities in soil, plant species richness and abundance which should be considered in future studies.

\section{Further Research}

Farmers and foresters are expected to fulfill multiple functions for society: to produce food, fiber and fuel and to provide jobs for people living in rural areas whilst simultaneously protecting the environment, preserving the landscape and biodiversity. The EU has developed the Common Agricultural Policy (CAP) to attract young farmers to join the profession and to provide a sustainable and competitive agricultural sector that ensures safe, affordable and good quality food, while preserving biodiversity, and to mitigate the uncertainties arising from climate change, price fluctuations in agricultural markets, and political decision-making (EC, 2020). The proposals for the post-2020 CAP focus on increased subsidiarity and result-based schemes, rather than centralized activity based interventions. The basic policy parameters, included in new CAP, will allow for more flexibility and require national level customization in the form of a National Strategic Plans by each Member State that accounts for national contexts (EC, 2017). This development offers opportunities for the creation of targeted and effective policies for agricultural and environmental development that will allow for differentiation at regional level.

In the context of Latvia, such differentiation requires further quantification of and optimization of the three soil functions, and validation of the proposed changes in land use and management practices, specifically for abandoned agricultural lands that provide opportunities for win:win:win outcomes. Abandoned agricultural land are typically naturally overgrown with bushes; targeted afforestation of these areas cannot only lead to long-term economic benefits, but also create an important carbon sink of wood biomass (Hooker and Compton, 2017), while maintaining the heterogeneity of the landscape can have a positive impact on the bird species richness and abundance (Pedersen and Krøgli, 2017). The territory of Latvia is characterized by unstable climatic conditions with intermittent occurrences of frost, drought and rain events and shifting from crops to higher value-added products (without financial support for investments and insurance) can lead to financial losses. Therefore, expansion of current production is considered a more readily achievable solution for short-term economic returns. However, of equal importance to the design of regional intervention packages is the identification of the gaps between design and implementation, known as the "thinkdo-gap" (O'Sullivan et al., 2017). This entails the identification of suitable pathways for the incentivization of changes in land use and management practices for individual land managers. This combination of design and identification of transition pathways may then inform national policies to optimize the supply of soil functions and to achieve the socio-economic and climate objectives simultaneously in the context of national and international commitments and the new CAP.

\section{CONCLUSION}

- In conclusion, the supply and demand for soil functions differ between regions. The supply of soil functions can be improved by changes in land use and improvements in management practices, but these should be applied in accordance with regional and national targets and commitments without undue trade-offs with the supply of other soil functions.

- Increasing demand for bio-based products allows countries such as Latvia, where economic development has been impacted by various economical changes, to increase biobased production and exports. Trade-offs between an increase in production and climate change mitigation play an important role in policy decisions.

- Our results show that regions have specific suites of soil functions depending on land use and soil classes; also, the demand for primary productivity varies between regions while the demand for biodiversity is locally spread, but the demand for climate mitigation is framed for the country as a whole.

- Regional differences define specific requirements for land use changes or improvements in management practices. In order to promote sustainable development of agriculture and forestry, policy-making should consider regional differences to achieve both socio-economic and climate objectives. We have identified spatial locations for specific land use changes and improvements in management practices related to the supply and demand for the three soil functions.

- Proposed changes to the common agricultural policy offer the opportunity for each Member State to form an agricultural policy at national scale to underpin agricultural practices that are effective and tailored toward local climate conditions and national implementation pathways.

\section{DATA AVAILABILITY STATEMENT}

The raw data supporting the conclusions of this article will be made available by the authors, without undue reservation.

\section{AUTHOR CONTRIBUTIONS}

$\mathrm{KV}$, $\mathrm{AN}$, and $\mathrm{RS}$ conceived the idea. $\mathrm{KV}$ and $\mathrm{AL}$ conducted the analysis. $\mathrm{KV}, \mathrm{AN}, \mathrm{AL}$, and $\mathrm{RS}$ wrote the 
manuscript. All authors contributed to the article and approved the submitted version.

\section{FUNDING}

This work was part of the LANDMARK (LAND Management: Assessment, Research, Knowledge Base) project, funded by the EU's Horizon 2020 Research and Innovation Program under grant agreement no. 635201 (www.landmark2020.eu). This study also was partly

\section{REFERENCES}

Ausec, L., Kraigher, B., and Mandic-Mulec, I. (2009). Differences in the activity and bacterial community structure of drained grassland and forest peat soils. Soil Biol. Biochem. 41, 1874-1881. doi: 10.1016/J.SOILBIO.2009. 06.010

Bardule, A., Lupikis, A., Butlers, A., and Lazdins, A. (2017). Organic carbon stock in different types of mineral soils in cropland and grassland in Latvia. Zemdirbyste Agric. 104, 3-8. doi: 10.13080/z-a.2017.104.001

Berglund, Ö, and Berglund, K. (2010). Distribution and cultivation intensity of agricultural peat and gyttja soils in Sweden and estimation of greenhouse gas emissions from cultivated peat soils. Geoderma 154, 173-180. doi: 10.1016/J. GEODERMA.2008.11.035

Bharali, A., Baruah, K. K., Bhattacharyya, P., and Gorh, D. (2017). Integrated nutrient management in wheat grown in a northeast India soil: impacts on soil organic carbon fractions in relation to grain yield. Soil Tillage Res. 168, 81-91. doi: $10.1016 /$ j.still.2016.12.001

Blanco-Canqui, H., and Lal, R. (2004). Mechanisms of carbon sequestration in soil aggregates. Crit. Rev. Plant Sci. 23, 481-504. doi: 10.1080/07352680490886842

Bölenius, E., Stenberg, B., and Arvidsson, J. (2017). Within field cereal yield variability as affected by soil physical properties and weather variations - a case study in east central Sweden. Geoderma Reg. 11, 96-103. doi: 10.1016/j.geodrs. 2017.11.001

Bretagnolle, V., Siriwardena, G., Miguet, P., Henckel, L., and Kleijn, D. (2019). Local and landscape scale effects of heterogeneity in shaping bird communities and population dynamics: crop-grassland interactions. Agroecosyst. Divers. 2019, 231-243. doi: 10.1016/B978-0-12-811050-8.00014-5

Calzolari, C., Ungaro, F., Filippi, N., Guermandi, M., Malucelli, F., Marchi, N., et al. (2016). A methodological framework to assess the multiple contributions of soils to ecosystem services delivery at regional scale. Geoderma 261, 190-203. doi: 10.1016/J.GEODERMA.2015.07.013

Carrasco, L., Norton, L., Henrys, P., Siriwardena, G. M., Rhodes, C. J., Rowland, C., et al. (2018). Habitat diversity and structure regulate British bird richness: implications of non-linear relationships for conservation. Biol. Conserv. 226, 256-263. doi: 10.1016/J.BIOCON.2018.08.010

Cedro, A., and Lamentowicz, M. (2011). Contrasting responses to environmental changes by pine (Pinus sylvestris L.) growing on peat and mineral soil: an example from a Polish Baltic bog. Dendrochronologia 29, 211-217. doi: 10.1016/ J.DENDRO.2010.12.004

Chan, K. (2001). An overview of some tillage impacts on earthworm population abundance and diversity - implications for functioning in soils. Soil Tillage Res. 57, 179-191. doi: 10.1016/S0167-1987(00)00173-2

Conant, R. T., Paustian, K., and Elliott, E. T. (2001). Grassland management and conversion into grassland: effects on soil carbon. Ecol. Appl. 11, 343-355. doi: 10.1890/1051-0761(2001)011[0343:gmacig]2.0.co;2

Coyle, C., Creamer, R. E., Schulte, R. P. O., O’Sullivan, L., and Jordan, P. (2016). A functional land management conceptual framework under soil drainage and land use scenarios. Environ. Sci. Policy 56, 39-48. doi: 10.1016/J.ENVSCI.2015. 10.012

De Baan, L., Alkemade, R., and Koellner, T. (2013). Land use impacts on biodiversity in LCA: a global approach. Int. J. Life Cycle Assess. 18, 1216-1230. doi: $10.1007 /$ s11367-012-0412-0 financed by "Strengthening Research Capacity in the Latvia University of Life Sciences and Technologies" (Z26) project.

\section{SUPPLEMENTARY MATERIAL}

The Supplementary Material for this article can be found online at: https://www.frontiersin.org/articles/10.3389/fenvs. 2020.591695/full\#supplementary-material

de Groot, R. S., Alkemade, R., Braat, L., Hein, L., and Willemen, L. (2010) Challenges in integrating the concept of ecosystem services and values in landscape planning, management and decision making. Ecol. Complex. 7, 260-272. doi: 10.1016/j.ecocom.2009.10.006

de Ruiter, P. C., and Brown, G. G. (2007). Soil biodiversity for agricultural sustainability. Agric. Ecosyst. Environ. 121, 233-244. doi: 10.1016/J.AGEE.2006. 12.013

de Vries, F. T., Thebault, E., Liiri, M., Birkhofer, K., Tsiafouli, M. A., Bjornlund, L., et al. (2013). Soil food web properties explain ecosystem services across European land use systems. Proc. Natl. Acad. Sci. U.S.A. 110, 14296-14301. doi: 10.1073/pnas.1305198110

Dickie, I. A., Yeates, G. W., St. John, M. G., Stevenson, B. A., Scott, J. T., Rillig, M. C., et al. (2011). Ecosystem service and biodiversity trade-offs in two woody successions. J. Appl. Ecol. 48, 926-934. doi: 10.1111/j.1365-2664.2011.0 1980.x

Dimitriou, I., and Dominik, R. (2015). Ilgtspējīgi ìscirtmeta Atvasāju Stādījumi. Rokasgrāmata, ed. D. Lazdina Minhene Vācija: WIP Renewable Energies.

Dingkuhn, E. L., Wezel, A., Bianchi, F. J. J. A., Groot, J. C. J., Wagner, A., Yap, H. T., et al. (2020). A multi-method approach for the integrative assessment of soil functions: application on a coastal mountainous site of the Philippines. J. Environ. Manage. 264:110461. doi: 10.1016/j.jenvman.2020.110461

Dominati, E., Patterson, M., and Mackay, A. (2010). A framework for classifying and quantifying the natural capital and ecosystem services of soils. Ecol. Econ. 69, 1858-1868. doi: 10.1016/j.ecolecon.2010. 05.002

EC (2006). Thematic Strategy for Soil Protection. Brussels: European Commission.

EC (2014). 2030 Climate \& Energy Framework. Brussels: European Commission, $1-5$.

EC (2017). Communication From the Comission to the European Parliament, the Council, the European Economic and Social Committee and the Committee of the Regions, The future of Food and Farming COM(2017) 713 Final. Brussels: European Commission.

EC (2020). The Common Agricultural Policy at a Glance. Brussels: European Commission.

Ekonomikas ministrija (2018). Latvijas Nacionālais Energétikas un Klimata Plāns 2021. - 2030. Gadam (in Latvian). Riga: Ekonomikas ministrija.

Eory, V., Pellerin, S., Carmona Garcia, G., Lehtonen, H., Licite, I., Mattila, H., et al. (2018). Marginal abatement cost curves for agricultural climate policy: stateof-the art, lessons learnt and future potential. J. Clean. Prod. 182, 705-716. doi: 10.1016/J.JCLEPRO.2018.01.252

Ernst, L. M., Tscharntke, T., and Batáry, P. (2017). Grassland management in agricultural vs. forested landscapes drives butterfly and bird diversity. Biol. Conserv. 216, 51-59. doi: 10.1016/J.BIOCON.2017. 09.027

EU (2018). Regulation (EU) 2018/842 of the European Parliament and of the Councilnof 30 May 2018 on binding annual greenhouse gas emission reductions by Member States from 2021 to 2030 contributing to climate action to meet commitments under the Paris Agreement. Off. J. Eur. Union 2018, $26-42$.

Eurostat (2020). National Accounts Aggregates by Industry (up to NACE $A^{*} 64$ ) [NAMA_10_A64]. Luxembourg: Eurostat 
Fortier, J., Truax, B., Gagnon, D., and Lambert, F. (2015). Biomass carbon, nitrogen and phosphorus stocks in hybrid poplar buffers, herbaceous buffers and natural woodlots in the riparian zone on agricultural land. J. Environ. Manage. 154, 333-345. doi: 10.1016/J.JENVMAN.2015.02.039

Frelechoux, F., Buttler, A., Schweingruber, F. H., and Gobat, J.-M. (2000). Stand structure, invasion, and growth dynamics of bog pine (Pinus uncinata var. rotundata) in relation to peat cutting and drainage in the Jura Mountains, Switzerland. Can. J. For. Res. 30, 1114-1126. doi: 10.1139/cjfr-30-71114

Gosling, P., Van Der Gast, C., and Bending, G. D. (2017). Converting highly productive arable cropland in Europe to grassland: - a poor candidate for carbon sequestration. Sci. Rep. 7, 1-12. doi: 10.1038/s41598-017-11 083-6

Greiner, L., Keller, A., Grêt-Regamey, A., and Papritz, A. (2017). Soil function assessment: review of methods for quantifying the contributions of soils to ecosystem services. Land Use Policy 69, 224-237. doi: 10.1016/J.LANDUSEPOL. 2017.06.025

Greiner, L., Nussbaum, M., Papritz, A., Fraefel, M., Zimmermann, S., Schwab, P., et al. (2018). Assessment of soil multi-functionality to support the sustainable use of soil resources on the Swiss Plateau. Geoderma Reg. 14:e00181. doi: 10. 1016/J.GEODRS.2018.E00181

Hedley, C. (2015). The role of precision agriculture for improved nutrient management on farms. J. Sci. Food Agric. 95, 12-19. doi: 10.1002/js fa. 6734

Hénault-Ethier, L., Gomes, M. P., Lucotte, M., Smedbol, É, Maccario, S., Lepage, L., et al. (2017). High yields of riparian buffer strips planted with Salix miyabena 'SX64' along field crops in Québec, Canada. Biomass Bioenergy 105, 219-229. doi: 10.1016/j.biombioe.2017.06.017

Hooker, T. D., and Compton, J. E. (2017). Forest Ecosystem Carbon and Nitrogen Accumulation During the First Century After Agricultural Abandonment. Ithaca, NY: Ecological Society of America.

IPCC (2014). 2013 Supplement to the 2006 IPCC Guidelines for National Greenhouse Gas Inventories: Wetlands. Switzerland: IPCC. Available online at: http://www.ipcc-nggip.iges.or.jp

IUSS Working Group WRB (2015). International Soil Classification System for Naming Soils and Creating Legends for Soil Maps. Rome: ISRIC.

Jiang, D., Fan, X., Dai, T., and Cao, W. (2008). Nitrogen fertiliser rate and post-anthesis waterlogging effects on carbohydrate and nitrogen dynamics in wheat. Plant Soil 304, 301-314. doi: 10.1007/s11104-0089556-X

Karki, S., Elsgaard, L., Kandel, T. P., and Lærke, P. E. (2016). Carbon balance of rewetted and drained peat soils used for biomass production: a mesocosm study. GCB Bioenergy 8, 969-980. doi: 10.1111/gcbb. 12334

Karlen, D. L., Mausbach, M. J., Doran, J. W., Cline, R. G., Harris, R. F., and Schuman, G. E. (1997). Soil quality: a concept, definition, and framework for evaluation (A Guest Editorial). Soil Sci. Soc. Am. J. 61:4. doi: 10.2136/sssaj1997. $03615995006100010001 x$

Kløve, B., Berglund, K., Berglund, Ö., Weldon, S., and Maljanen, M. (2017). Future options for cultivated Nordic peat soils: Can land management and rewetting control greenhouse gas emissions? Environ. Sci. Policy 69, 85-93. doi: 10.1016/ J.ENVSCI.2016.12.017

Laganière, J., Angers, D. A., and Paré, D. (2010). Carbon accumulation in agricultural soils after afforestation: a meta-analysis. Glob. Chang. Biol. 16, 439-453. doi: 10.1111/j.1365-2486.2009.01930.x

Lazdins, A., Lupikis, A., Lazdina, D., and Bebre, I. (2014). "Case studies of afforestation of organic soils in Latvia - costs, benefits \& climate change mitigation," in Proceedings of the 15th Baltic Peat Producers Forum, Daugavpils, $1-14$.

Lazdinš̌, A., Okmanis, M., Polmanis, K., Spalva, G., Lupiķis, A., Bārdule, A., et al. (2015). Augsnes Oglekla Krājumu Novērtēšana Aramzemē un Plavās (in Latvian). Salaspils: Iceland Liechtenstein Norway.

Leppelt, T., Dechow, R., Gebbert, S., Freibauer, A., Lohila, A., Augustin, J., et al. (2014). Nitrous oxide emission budgets and land-use-driven hotspots for organic soils in Europe. Biogeosciences 11, 6595-6612. doi: 10.5194/bg-116595-2014

LIBRA2030 (2017). Latvian Bioeconomy Strategy 2030. Paris: FAO.
LVĢMC (2017). Klimata Pārmaiņu Scenāriji Latvijai, Ziņojuma Kopsavilkums (in Latvian), VSIA “Latvijas Vides, g̀eolog̀ijas un Meteorolog̀ijas Centrs.”. Riga: LVİMC.

LVĢMC (2018). Pārskats par Virszemes un Pazemes Ūdeņu Stāvokli 2018.Gadā. VSIA "Latvijas Vides, g̀eolog̀ijas un Meteorolog̀ijas Centrs" (in Latvian). Rīga: LVİMC.

Maanavilja, L., Kangas, L., Mehtätalo, L., and Tuittila, E. S. (2015). Rewetting of drained boreal spruce swamp forests results in rapid recovery of Sphagnum production. J. Appl. Ecol. 52, 1355-1363. doi: 10.1111/1365-2664. 12474

Mäkiranta, P., Hytönen, J., Aro, L., Maljanen, M., Pihlatie, M., Potila, H., et al. (2007). Soil greenhouse gas emissions from afforested organic soil croplands and cutaway peatlands. Boreal Environ. Res. 12, 159-175.

Maljanen, M., Sigurdsson, B. D., Guð̋mundsson, J., Óskarsson, H., Huttunen, J. T., and Martikainen, P. J. (2010). Greenhouse gas balances of managed peatlands in the Nordic countries - present knowledge and gaps. Biogeosciences 7, 2711-2738. doi: 10.5194/bg-7-2711-2010

Mander, Ü, Järveoja, J., Maddison, M., Soosaar, K., Aavola, R., Ostonen, I., et al. (2012). Reed canary grass cultivation mitigates greenhouse gas emissions from abandoned peat extraction areas. GCB Bioenergy 4, 462-474. doi: 10.1111/j. 1757-1707.2011.01138.x

Martínez, I., Chervet, A., Weisskopf, P., Sturny, W. G., Etana, A., Stettler, M., et al. (2016). Two decades of no-till in the Oberacker long-term field experiment: part I. Crop yield, soil organic carbon and nutrient distribution in the soil profile. Soil Tillage Res. 163, 141-151. doi: 10.1016/j.still.2016.05.021

Matysek, M., Leake, J., Banwart, S., Johnson, I., Page, S., Kaduk, J., et al. (2019). Impact of fertiliser, water table, and warming on celery yield and CO2 and CH4 emissions from fenland agricultural peat. Sci. Total Environ. 667, 179-190. doi: 10.1016/J.SCITOTENV.2019.02.360

McDaniel, M. D., Tiemann, L. K., and Grandy, A. S. (2014). Does agricultural crop diversity enhance soil microbial biomass and organic matter dynamics? A meta-analysis. Ecol. Appl. 24, 560-570. doi: 10.1890/13-0616.1

Meredith, S. (2019). Getting to the Roots of Sustainable Land Management: A Briefing on the Common Agricultural Policy in the EU Post-2020, Briefing for iSQAPER. London: Institute for European Environmental Policy. Available online at: https://ieep.eu/publications/policy-brief-getting-to-theroots-of-sustainable-land-management

Minkkinen, K., Vasander, H., Jauhiainen, S., Karsisto, M., and Laine, J. (1999). Post-drainage changes in vegetation composition and carbon balance in Lakkasuo mire, Central Finland. Plant Soil 207, 107-120.

Mueller, L., Schindler, U., Mirschel, W., Shepherd, T. G., Ball, B. C., Helming, K., et al. (2010). Assessing the productivity function of soils. A review. Agron. Sustain. Dev. 30, 601-614. doi: 10.1051/agro/2009057

Musarika, S., Atherton, C. E., Gomersall, T., Wells, M. J., Kaduk, J., Cumming, A. M. J., et al. (2017). Effect of water table management and elevated CO2 on radish productivity and on $\mathrm{CH} 4$ and $\mathrm{CO} 2$ fluxes from peatlands converted to agriculture. Sci. Total Environ. 58, 665-672. doi: 10.1016/J.SCITOTENV.2017. 01.094

Nielsen, U. N., Wall, D. H., and Six, J. (2015). Soil biodiversity and the environment. Annu. Rev. Environ. Resour. 40, 63-90. doi: 10.1146/annurevenviron-102014-021257

Nipers, A. (2019). Zemes izmantošanas Optimizācijas Iespēju Novērtējums Latvijas Klimata Politikas Kontekstā (in Latvian). Riga: JSC "Latvia's State Forests". Available online at: https://www.lvm.lv/images/lvm/Petijumi_un_publikacijas/ Petijumi/zemes-izmantosanas-optimizacija_2018.pdf

NIR (2018). LATVIA'S National Inventory Report 1990-2016. Rio de Janeiro: UNFCCC.

Ogle, S. M., Breidt, F. J., and Paustian, K. (2005). Agricultural management impacts on soil organic carbon storage under moist and dry climatic conditions of temperate and tropical regions. Biogeochemistry 72, 87-121. doi: 10.1007/ s10533-004-0360-2

Osterholz, W. R., Liebman, M., and Castellano, M. J. (2018). Can soil nitrogen dynamics explain the yield benefit of crop diversification? F. Crop. Res. 219, 33-42. doi: 10.1016/J.FCR.2018.01.026

O’Sullivan, L., Creamer, R. E., Fealy, R., Lanigan, G., Simo, I., Fenton, O., et al. (2015). Functional Land Management for managing soil functions: a case-study 
of the trade-off between primary productivity and carbon storage in response to the intervention of drainage systems in Ireland. Land Use Policy 47, 42-54. doi: 10.1016/J.LANDUSEPOL.2015.03.007

O’Sullivan, L., Wall, D., Creamer, R., Bampa, F., and Schulte, R. P. O. (2017). Functional land management: bridging the think-do-gap using a multistakeholder science policy interface. Ambio 47, 216-230. doi: 10.1007/s13280017-0983-x

Pedersen, C., and Krøgli, S. O. (2017). The effect of land type diversity and spatial heterogeneity on farmland birds in Norway. Ecol. Indic. 75, 155-163. doi: 10.1016/J.ECOLIND.2016.12.030

Pilvere, I., Nipers, A., Krieviņa, A., Bulderberga, Z., Zalūkssne, V., Sisenis, L., et al. (2015). Dažādu Zemes Apsaimniekošanas Modelu Sociāli Ekonomiskais Novērtējums (in Latvian). Riga: JSC "Latvia's State Forests". Available online at: https://www.lvm.lv/petijumi-un-publikacijas/dazadu-zemesapsaimniekosanas-modelu-sociali-ekonomiskais-novertejums

Pilvere, I., Nipers, A., Ozolinš̌, J., Zariņš, J., Upīte, I., Popluga, D., et al. (2017). Organisko Augšņu Devuma Novērtējums Latvijas Lauksaimniecībā Daudzfaktoru Ietekmes Izvērtējums Efektīvas Zemes Izmantošanas Risinājumu Piedāvājumā (in Latvian). Riga: The Ministry of Agriculture of the Republic of Latvia. Available online at: https://www.zm.gov.lv/public/files/CMS_Static Page_Doc/00/00/01/32/80/LLU_galaatskaite_INTERREGBIO4ECO.pdf

Pinillos, D., Bianchi, F. J. J. A., Poccard-Chapuis, R., Corbeels, M., Tittonell, P., and Schulte, R. P. O. (2020). Understanding landscape multifunctionality in a postforest frontier: supply and demand of ecosystem services in eastern amazonia. Front. Environ. Sci. 7:206. doi: 10.3389/fenvs.2019.00206

Poeplau, C., Don, A., Vesterdal, L., Leifeld, J., Van Wesemael, B., Schumacher, J., et al. (2011). Temporal dynamics of soil organic carbon after land-use change in the temperate zone - carbon response functions as a model approach. Glob. Chang. Biol. 17, 2415-2427. doi: 10.1111/j.1365-2486.2011. 02408.x

Ramesh, T., Bolan, N. S., Kirkham, M. B., Wijesekara, H., Kanchikerimath, M., Srinivasa Rao, C., et al. (2019). Soil organic carbon dynamics: impact of land use changes and management practices: a review. Adv. Agron. 156, 1-107. doi: 10.1016/BS.AGRON.2019.02.001

Reidsma, P., Tekelenburg, T., van den Berg, M., and Alkemade, R. (2006). Impacts of land-use change on biodiversity: an assessment of agricultural biodiversity in the European Union. Agric. Ecosyst. Environ. 114, 86-102. doi: 10.1016/J.AGEE. 2005.11.026

Remm, L., Lõhmus, P., Leis, M., and Lõhmus, A. (2013). Long-term impacts of forest ditching on non-aquatic biodiversity: conservation perspectives for a novel ecosystem. PLoS One 8:e63086. doi: 10.1371/journal.pone.0063086

Renou-Wilson, F., Müller, C., Moser, G., and Wilson, D. (2016). To graze or not to graze? Four years greenhouse gas balances and vegetation composition from a drained and a rewetted organic soil under grassland. Agric. Ecosyst. Environ. 222, 156-170. doi: 10.1016/J.AGEE.2016.02.011

Schrier-Uijl, A. P., Kroon, P. S., Hendriks, D. M. D., Hensen, A., Van Huissteden, J., Berendse, F., et al. (2014). Agricultural peatlands: towards a greenhouse gas sink - a synthesis of a Dutch landscape study. Biogeosciences 11, 4559-4576. doi: 10.5194/bg-11-4559-2014

Schulte, R. P. O., Bampa, F., Bardy, M., Coyle, C., Creamer, R. E., Fealy, R., et al. (2015). Making the most of our land: managing soil functions from local to continental scale. Front. Environ. Sci. 3:81. doi: 10.3389/fenvs.2015.00081

Schulte, R. P. O., Creamer, R. E., Donnellan, T., Farrelly, N., Fealy, R., O’Donoghue, C., et al. (2014). Functional land management: a framework for managing soil-based ecosystem services for the sustainable intensification of agriculture. Environ. Sci. Policy 38, 45-58. doi: 10.1016/J.ENVSCI.2013.10.002

Schulte, R. P. O., Fealy, R., Creamer, R. E., Towers, W., Harty, T., and Jones, R. J. A. (2012). A review of the role of excess soil moisture conditions in constraining farm practices under Atlantic conditions. Soil Use Manag. 28, 580-589. doi: 10.1111/j.1475-2743.2012.00437.x

Schulte, R. P. O., O'Sullivan, L., Vrebos, D., Bampa, F., Jones, A., and Staes, J. (2019). Demands on land: mapping competing societal expectations for the functionality of agricultural soils in Europe. Environ. Sci. Policy 100, 113-125. doi: 10.1016/J.ENVSCI.2019.06.011

Shurpali, N. J., Hyvönen, N. P., Huttunen, J. T., Clement, R. J., Reichstein, M., Nykänen, H., et al. (2009). Cultivation of a perennial grass for bioenergy on a boreal organic soil - carbon sink or source? GCB Bioenergy 1, 35-50. doi: $10.1111 / j .1757-1707.2009 .01003 . x$
Simpson, R. T., Frey, S. D., Six, J., and Thiet, R. K. (2010). Preferential accumulation of microbial carbon in aggregate structures of no-tillage soils. Soil Sci. Soc. Am. J. 68, 1249. doi: $10.2136 /$ sssaj2004.1249

Strazdina, B. (2015). Alternatìvas Biomasas Izmantošanas Iespējas Zālāju Biologiskās Daudzveidības un Ekosistēmu Pakalpojumu Uzturēšanai, LIFE+ Biodiversity (in Latvian). Riga: Latvian Fund for Nature. Available online at: https://ldf.lv/sites/default/files/faili/projekti/SIF/BVZ_seminars/1_biologiski_ vertigo_zalaju_raziba-baiba_strazdina.pdf

Sylvain, Z. A., and Wall, D. H. (2011). Linking soil biodiversity and vegetation: implications for a changing planet. Am. J. Bot. 98, 517-527. doi: 10.3732/ajb. 1000305

Taghizadeh-Toosi, A., and Olesen, J. E. (2016). Modelling soil organic carbon in Danish agricultural soils suggests low potential for future carbon sequestration. Agric. Syst. 145, 83-89. doi: 10.1016/J.AGSY.2016.03.004

Tavi, N. M., Koponen, H. T., Huttunen, J. T., Kekki, T. K., Biasi, C., and Martikainen, P. J. (2010). Impact of Phalaris arundinacea cultivation on microbial community of a cutover peatland. Boreal Environ. Res. 15, 437-445.

The European Parliament (2006). Communication From the Commission to the Council, the European Parliament, the European Economic and Social Committee and the Committee of the Regions. Brussels: The European Parliament.

The Parliament of the Republic of Latvia (2012). Law on Forests, Latvijas Vestnesis, 98/99 (2009/2010), 16.03.2000. Latvia: The Parliament of the Republic of Latvia.

Thomson, B. C., Tisserant, E., Plassart, P., Uroz, S., Griffiths, R. I., Hannula, S. E., et al. (2015). Soil conditions and land use intensification effects on soil microbial communities across a range of European field sites. Soil Biol. Biochem. 88, 403-413. doi: 10.1016/J.SOILBIO.201 5.06 .012

Tsiafouli, M. A., Thébault, E., Sgardelis, S. P., de Ruiter, P. C., van der Putten, W. H., Birkhofer, K., et al. (2015). Intensive agriculture reduces soil biodiversity across Europe. Glob. Chang. Biol. 21, 973-985. doi: 10.1111/gcb.12752

Tuck, S. L., Winqvist, C., Mota, F., Ahnström, J., Turnbull, L. A., and Bengtsson, J. (2014). Land-use intensity and the effects of organic farming on biodiversity: a hierarchical meta-analysis. J. Appl. Ecol. 51, 746-755. doi: 10.1111/1365-2664. 12219

UN (2015). Adoption of The Paris Agreement - Conference of the Parties COP 21. New York, NY: United Nation.

United Nations General Assembly (2015). Transforming Our World: The 2030 Agenda for Sustainable Development. New York, NY: United Nations General Assembly.

Valujeva, K., O’Sullivan, L., Gutzler, C., Fealy, R., and Schulte, R. P. O. (2016). The challenge of managing soil functions at multiple scales: an optimisation study of the synergistic and antagonistic trade-offs between soil functions in Ireland. Land Use Policy 58, 335-347. doi: 10.1016/j.landusepol.2016. 07.028

Van den Putte, A., Govers, G., Diels, J., Gillijns, K., and Demuzere, M. (2010). Assessing the effect of soil tillage on crop growth: a meta-regression analysis on European crop yields under conservation agriculture. Eur. J. Agron. 33, 231-241. doi: 10.1016/J.EJA.2010.05.008

van Leeuwen, C. C. E., Cammeraat, E. L. H., de Vente, J., and Boix-Fayos, C. (2019). The evolution of soil conservation policies targeting land abandonment and soil erosion in Spain: a review. Land use policy 83, 174-186. doi: 10.1016/j. landusepol.2019.01.018

Van Vooren, L., Reubens, B., Broekx, S., Reheul, D., and Verheyen, K. (2018). Assessing the impact of grassland management extensification in temperate areas on multiple ecosystem services and biodiversity. Agric. Ecosyst. Environ. 267, 201-212. doi: 10.1016/J.AGEE.2018.08.016

Vrebos, D., Jones, A., Lugato, E., O’Sullivan, L., Schulte, R., Staes, J., et al. (2020). Spatial evaluation and trade-off analysis of soil functions through Bayesian networks. Eur. J. Soil Sci. 2020, 1-15. doi: 10.1111/ejss. 13039

Wagg, C., Bender, S. F., Widmer, F., and van der Heijden, M. G. A. (2014). Soil biodiversity and soil community composition determine ecosystem multifunctionality. Proc. Natl. Acad. Sci. U.S.A. 111, 5266-5270. doi: 10.1073/ pnas.1320054111

Weslien, P., Kasimir Klemedtsson, Å, Börjesson, G., and Klemedtsson, L. (2009). Strong $\mathrm{pH}$ influence on $\mathrm{N} 2 \mathrm{O}$ and $\mathrm{CH} 4$ fluxes from forested organic soils. Eur. J. Soil Sci. 60, 311-320. doi: 10.1111/j.1365-2389.2009.01123.x 
Weslien, P., Rütting, T., Kasimir-Klemedtsson, Å, and Klemedtsson, L. (2012). Carrot cropping on organic soil is a hotspot for nitrous oxide emissions. Nutr. Cycl. Agroecosyst. 94, 249-253. doi: 10.1007/s10705-012-9538-5

West, T. O., and Post, W. M. (2002). Soil organic carbon sequestration rates by tillage and crop rotation: a global data analysis. Soil Sci. Soc. Am. J. 66, 1930-1946. doi: 10.2136/sssaj2002.1930

Wuczyński, A. (2016). Farmland bird diversity in contrasting agricultural landscapes of southwestern Poland. Landsc. Urban Plan. 148, 108-119. doi: 10.1016/J.LANDURBPLAN.2015.11.010

Zalitis, P., and Indriksons, A. (2009). The hydrological properties of waterlogged and drained forests in Latvia. J. Water L. Dev. 13, 69-86. doi: 10.2478/v10025010-0006-9

Zhang, H., Turner, N. C., Poole, M. L., and Simpson, N. (2006). Crop production in the high rainfall zones of southern Australia - potential, constraints and opportunities. Aust. J. Exp. Agric. 46, 1035-1049. doi: 10.1071/EA05150

Zingg, S., Grenz, J., and Humbert, J.-Y. (2018). Landscape-scale effects of land use intensity on birds and butterflies. Agric. Ecosyst. Environ. 267, 119-128. doi: 10.1016/J.AGEE.2018.08.014
Zuber, S. M., Behnke, G. D., Nafziger, E. D., and Villamil, M. B. (2015). Crop rotation and tillage effects on soil physical and chemical properties in Illinois. Agron. J. 107, 971-978. doi: 10.2134/agronj14.0465

Zwetsloot, M. J., van Leeuwen, J., Hemerik, L., Martens, H., Simó Josa, I., Van de Broek, M., et al. (2020). Soil multifunctionality: synergies and trade-offs across European climatic zones and land uses. Eur. J. Soil Sci. 2020, 1-15. doi: $10.1111 /$ ejss.13051

Conflict of Interest: The authors declare that the research was conducted in the absence of any commercial or financial relationships that could be construed as a potential conflict of interest.

Copyright (C) 2020 Valujeva, Nipers, Lupikis and Schulte. This is an open-access article distributed under the terms of the Creative Commons Attribution License (CC BY). The use, distribution or reproduction in other forums is permitted, provided the original author(s) and the copyright owner(s) are credited and that the original publication in this journal is cited, in accordance with accepted academic practice. No use, distribution or reproduction is permitted which does not comply with these terms. 